\title{
NITRATE IN GROUND WATER AND SURFACE WATER IN A RESIDENTIAL SUBDIVISION, WEST WINDSOR TOWNSHIP, MERCER COUNTY, NEW JERSEY, 1993
}

By Glen B. Carleton and Eric F. Vowinkel

U.S. GEOLOGICAL SURVEY

Open-File Report 96-576

Prepared in cooperation with the

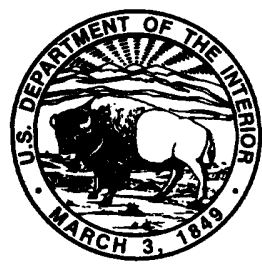

WEST WINDSOR TOWNSHIP ENVIRONMENTAL COMMISSION and the NEW JERSEY DEPARTMENT OF ENVIRONMENTAL PROTECTION

West Trenton, New Jersey 


\section{U.S. DEPARTMENT OF THE INTERIOR}

BRUCE BABBIT, Secretary

U.S. GEOLOGICAL SURVEY

Gordon P. Eaton, Director

For additional information write to:

District Chief

U.S. Geological Survey

810 Bear Tavern Road, Suite 206

West Trenton, NJ 08628-1022
Copies of this report can be obtained from:

U.S. Geological Survey

Branch of Information Services Box 25286

Denver, CO 80225-0286 


\section{CONTENTS}

Page

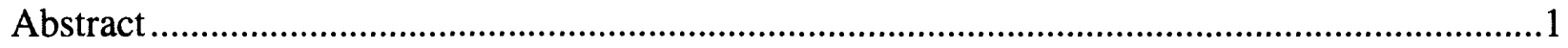

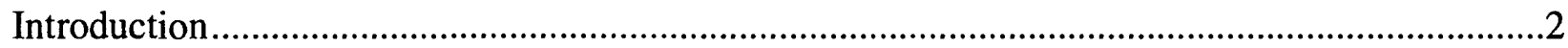

Purpose and scope

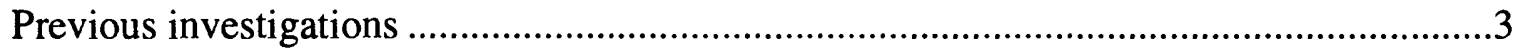

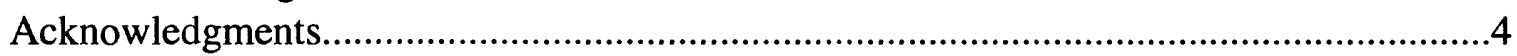

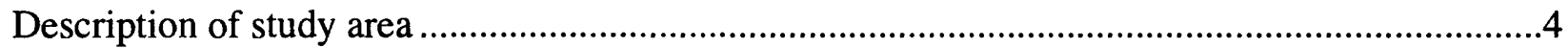

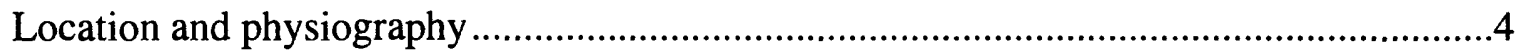

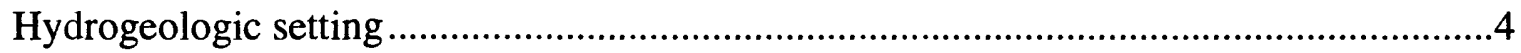

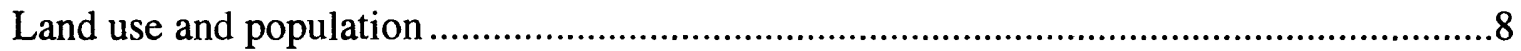

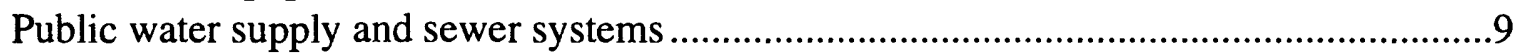

Historical nitrate concentrations in ground water ...........................................................10

Nitrate in ground water and surface water in a residential subdivision .......................................16

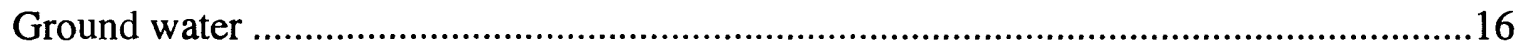

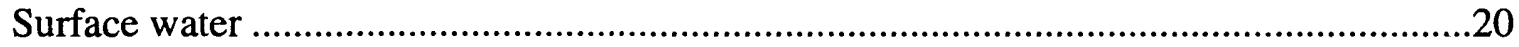

Estimated nitrate concentrations in ground-water recharge from residential land ............22

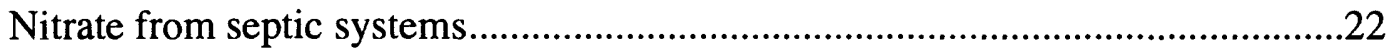

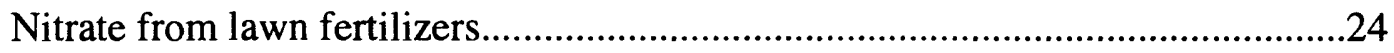

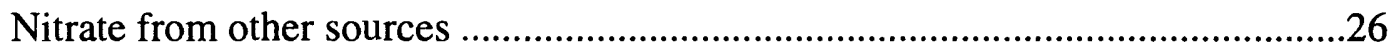

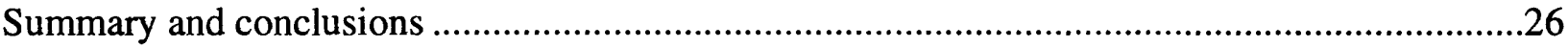

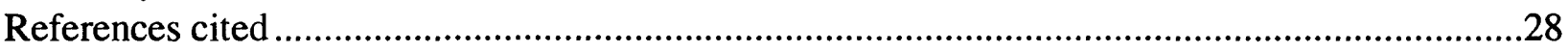

Appendix 1. Well-location, well-construction, and aquifer data for selected wells in West

Windsor Township, New Jersey ...........................................................................................33

\section{ILLUSTRATIONS}

Figure 1. Map showing location of study area, West Windsor Township, Mercer

County, New Jersey ........................................................................................

2. Map showing location of geologic formation outcrops, West Windsor

Township, New Jersey .....................................................................................6

3. Graph showing population of West Windsor Township, New Jersey,

1930-90.

4. Map showing location of sewered and unsewered areas and public

supply wells in West Windsor Township, New Jersey

5. Map showing concentrations of nitrate as nitrogen in water samples

from selected wells, West Windsor Township, New Jersey, 1985-93_.................15

6. Map showing location of five wells, two staff gages, and three surfacewater-quality sampling sites in the vicinity of the West Windsor Estates subdivision, West Windsor Township, New Jersey

7. Graph showing concentrations of nitrate as nitrogen in samples from five wells in the West Windsor Estates subdivision, West Windsor

Township, New Jersey, February 1989, May 1989, and September 1993. 


\section{TABLES}

Table 1. Geologic and hydrogeologic units, West Windsor Township, New Jersey

2. Area and percentage of land occupied by six land-use/land-cover types in West Windsor Township, New Jersey, 1985

3. Concentrations of constituents in samples from selected wells, West Windsor Township, New Jersey, 1949-93.

4. Water levels in five wells and at two surface-water gage sites located in the vicinity of the West Windsor Estates subdivision, West Windsor Township, New Jersey, 1993-94.

5. Concentrations of constituents in samples from selected surface-water sites, West Windsor Township, New Jersey, 1993

6. Low, medium, and high estimates of concentrations of nitrate in groundwater recharge from septic systems, West Windsor Estates subdivision, West Windsor Township, New Jersey, and parameters and equations used to calculate estimates

7. Low, medium, and high estimates of concentrations of nitrate in groundwater recharge from lawns, West Windsor Estates subdivision, West Windsor Township, New Jersey, and parameters and equations used to calculate estimates 


\section{CONVERSION FACTORS}

Multiply

foot (ft)

mile (mi)
By

\section{Length}

0.3048

1.609

Area

acre

acre

square mile $\left(\mathrm{mi}^{2}\right)$

gallon (gal)

4,047

0.4047

2.590

Volume

3.785
Flow

cubic foot per second $\left(\mathrm{ft}^{3} / \mathrm{s}\right)$

gallon per day (gal/d)

million gallons per day $(\mathrm{Mgal} / \mathrm{d})$

pound, avoirdupois (lb)

pound per 1,000 square feet $\left(\mathrm{lb} / 1,000 \mathrm{ft}^{2}\right)$
0.02832

0.003785

0.04381

\section{$\underline{\text { Mass }}$}

0.4536

\section{Mass per Area}

48.81
To obtain

meter

kilometer

square meter

hectare

square kilometer

liter

cubic meter per second cubic meter per day cubic meter per second

kilogram

kilogram per hectare

Sea level: In this report "sea level" refers to the National Geodetic Vertical Datum of 1929-- a geodetic datum derived from a general adjustment of the first-order level nets of the United States and Canada, formerly called Sea Level Datum of 1929.

Water-quality abbreviations:

$\mathrm{mg} / \mathrm{L}$ - milligrams per liter

$\mu \mathrm{g} / \mathrm{L} \quad$ - micrograms per liter 


\title{
NITRATE IN GROUND WATER AND SURFACE WATER IN A RESIDENTIAL SUBDIVISION, WEST WINDSOR TOWNSHIP, MERCER COUNTY, NEW JERSEY, 1993
}

\author{
By Glen B. Carleton and Eric F. Vowinkel
}

\begin{abstract}
Concentrations of nitrate (as nitrogen) greater than $1 \mathrm{mg} / \mathrm{L}$ are present in ground water throughout West Windsor Township in Mercer County, New Jersey, as a result of human activities. Concentrations of nitrate ranged from less than 0.1 to $15 \mathrm{mg} / \mathrm{L}$ in water samples collected by the U.S. Geological Survey (USGS) during 1985-93 from wells located in the township. The median nitrate concentration for 18 ground-water samples collected in the township during 1985-93 was about $8.5 \mathrm{mg} / \mathrm{L}$, the same as the median concentration for samples collected from shallow wells located in agricultural areas and completed in the Potomac-RaritanMagothy aquifer system. Agricultural fertilizers are a major source of nitrate in ground water in the township, but on-site septic systems and lawn fertilizers used in residential areas also are important sources of nitrate.
\end{abstract}

To quantify the effects of land-use change on the concentration of nitrate in ground water, samples were collected from five shallow (less than 50-ft deep) observation wells located in a residential subdivision constructed on formerly agricultural land. The median nitrate concentration in water from the five wells decreased from $15 \mathrm{mg} / \mathrm{L}$ in February 1989 to $10 \mathrm{mg} / \mathrm{L}$ in September 1993. The decrease in median nitrate concentration indicates that the conversion from agricultural to residential land use resulted in a lower nitrate input rate, but the decrease also could have been caused, in part, by a lower nitrate input rate during construction of the subdivision.

Low, medium, and high estimates of nitrate concentrations in ground-water recharge from septic systems and lawn fertilizers in the subdivision were made by using average recharge rates and the estimated nitrate contribution from each source. The medium estimated nitrate concentration for septic systems and lawn fertilizers is $4 \mathrm{mg} / \mathrm{L}$ and $3 \mathrm{mg} / \mathrm{L}$, respectively, resulting in a combined estimate of $7 \mathrm{mg} / \mathrm{L}$, which is slightly lower than the median nitrate concentration of $10 \mathrm{mg} / \mathrm{L}$ for the five ground-water samples collected in 1993. The estimated concentrations of nitrate from septic systems and lawn fertilizers in ground-water recharge could differ significantly from the actual value because most of the values used to estimate the nitrate concentrations were themselves estimated on the basis of the results of studies conducted elsewhere.

Concentrations of nitrate as nitrogen in samples collected from Bear Brook and the Millstone River in 1993 ranged from 2 to $5 \mathrm{mg} / \mathrm{L}$. Concentrations of nitrate as nitrogen in precipitation and a stormwater-runoff sample were less than $0.5 \mathrm{mg} / \mathrm{L}$. No known point sources of nitrate, such as sewage-treatment plants, are located on Bear Brook; therefore, the nitrate in the brook is probably transported to the brook by ground water. 


\section{INTRODUCTION}

Unnaturally high concentrations of nitrate in ground water and surface water can have an adverse effect on humans and stream ecosystems. Although nitrate itself is relatively nontoxic, it can be reduced bacterially to nitrite in the intestines of newborn infants and can result in methemoglobinemia (blue baby syndrome) (Madison and Brunett, 1985, p.93). The U.S. Environmental Protection Agency Maximum Contaminant Level (MCL) for nitrate as nitrogen in potable water is $10 \mathrm{mg} / \mathrm{L}$ (U.S. Environmental Protection Agency, 1990a). An MCL is the maximum permissible concentration of a contaminant in water that is delivered to any user of a public water system. Ground water or surface water with nitrate concentrations greater than the drinking water MCL must be treated before use as potable water. Elevated concentrations of nitrate in surface water can promote plant growth and eutrophication of lakes. Sources of nitrate include agricultural fertilizers, lawn fertilizers, septic-system effluent, sewage-treatment-plant discharge, animal wastes, and leaky sewer pipes. Nitrate concentrations in ground water probably change when overlying land is converted from agricultural use to residential use with on-site septic systems.

Nitrogen is present in ground water and surface water as nitrate $\left(\mathrm{NO}_{3}{ }^{-}\right)$, nitrite $\left(\mathrm{NO}_{2}{ }^{-}\right)$, ammonia $\left(\mathrm{NH}_{4}{ }^{+}\right)$, organic nitrogen, and nitrogen gas $\left(\mathrm{N}_{2}\right)$. Ammonia is the predominant form of nitrogen in agricultural fertilizers and septic-system effluents, but in the presence of oxygen it is converted to nitrite, then nitrate through nitrification (Hem, 1985, p. 124). Ammonia is soluble in water; however, it is a positively charged ion and readily sorbs to soil particles, which limits its mobility. Nitrate, which is also soluble in water, is a negatively charged ion that is not readily sorbed and is, therefore, highly mobile. Nitrate can be converted to nitrous oxide or nitrogen gas through denitrification, but can persist for years in ground water that contains oxygen (Hem, 1985 , p. 124). Nitrate present in surface water or in ground water that is shallow enough to be reached by plant roots can be removed by the plants.

Concern over elevated concentrations of nitrate in ground water and surface water has led water-resource managers to initiate studies to evaluate ground-water and surface-water quality. The U.S. Geological Survey (USGS), in cooperation with the West Windsor Township Environmental Commission and the New Jersey Department of Environmental Protection, conducted a study to assess the concentration of nitrate in ground water and surface water in a residential subdivision built on formerly agricultural land and to estimate the concentration of nitrate in ground-water recharge in the subdivision.

\section{Purpose and Scope}

This report presents (1) selected data from previous hydrogeologic and ground-waterquality studies in and around West Windsor Township, (2) results of analyses of water samples collected from five wells in a residential subdivision in the eastern part of West Windsor Township during 1985-93 and four nearby surface-water sites during 1993, (3) a comparison of nitrate concentrations in water samples collected in 1989 and 1993 from the five wells to evaluate the effects of converting agricultural land to a residential subdivision, and (4) estimates of nitrate concentrations in ground-water recharge from septic systems and lawn fertilizers in the subdivision. 


\section{Previous Investigations}

Several studies of ground-water quality have been conducted in and near West Windsor Township. Vecchioli and Palmer (1962) documented elevated concentrations of nitrate in ground water in West Windsor Township in samples collected in 1958. Vowinkel and Battaglin (1989) and Vowinkel (1991) showed that concentrations of nitrate in ground-water samples differed significantly among areas of different land use in the outcrop area of the Potomac-RaritanMagothy aquifer system from Middlesex to Salem Counties. The median concentration of nitrate as nitrogen in shallow ground water was $8.5 \mathrm{mg} / \mathrm{L}$ in agricultural areas, $3.6 \mathrm{mg} / \mathrm{L}$ in residential areas, $0.8 \mathrm{mg} / \mathrm{L}$ in urban-nonresidential areas, and less than $0.1 \mathrm{mg} / \mathrm{L}$ in undeveloped areas. Vowinkel and Tapper (1995) analyzed the relation of land use and hydrogeology to water quality, including nitrogen-isotope ratios, in the Potomac-Raritan-Magothy aquifer system in Middlesex and Mercer Counties and in the Kirkwood-Cohansey aquifer system. Results from this study indicated that the predominant source of nitrate in water from domestic wells in agricultural areas is chemical fertilizers used on crops, not septic systems. Murphy (1992) studied nitrate concentrations in water samples collected by well owners from 283 domestic and 60 public supply wells screened in Coastal Plain aquifers in Mercer and Burlington Counties. Results of this study indicated a significant relation between the concentration of nitrate in ground water and well depth, use of chemical or organic fertilizers, and the presence of a septic tank within $125 \mathrm{ft}$ of the well.

In the late 1980's the West Windsor Township commissioned a study of nitrates in ground water in the vicinity of the West Windsor Estates residential subdivision to establish a baseline from which to quantify the effect of converting the land use from agricultural to residential (BCM Engineers, Inc., 1990). Concentrations of nitrate were greater than $10 \mathrm{mg} / \mathrm{L}$ in water samples from all five wells installed and sampled by BCM Engineers, Inc., in the vicinity of the subdivision. The results of the BCM study prompted the township to compile available data on nitrate in ground-water samples collected from public supply, domestic, and observation wells throughout the township (Hary, 1990). Water from all 21 of the wells sampled for this study contained concentrations of nitrate as nitrogen equal to or greater than $1 \mathrm{mg} / \mathrm{L}$, indicating that water quality in each of these wells was affected by human activities at the land surface (Perlmutter and Koch, 1972).

Several studies of surface-water resources and surface-water quality were conducted in and near West Windsor Township. Geraghty and Miller (1972) described the surface-water resources of the upper Millstone River Basin. The New Jersey Department of Environmental Protection (NJDEP) conducted studies of water quality in the upper Millstone River Basin, which includes West Windsor Township and townships to the north and east, in 1987 and 1990. These studies included an analysis conducted by using mathematical models to determine the effects of land use and point and non-point sources of contamination on surface-water quality. The West Windsor Environmental Commission $(1990,1994)$ collected water samples quarterly at 8 stream and 13 detention-basin sites during 1982-92. Results of analyses of these samples showed that concentrations of contaminants, including nitrate, phosphorous, and fecal-coliform bacteria, were high enough to indicate that water quality is affected by human activities. Average nitrate concentrations in surface water were lower than or similar to those found in ground water throughout the township. 


\section{Acknowledgments}

For the information and data they provided, the authors thank the members of the West Windsor Township Environmental Commission, including Elaine Ballai and Diane White, and former member John Roeder; Samuel Surtees, Karen Johnson, and Susan Appelget of the Community Development Department; Robert Korkuch of the Engineering Department; and Robert Hary and Sharon Black of the Health Department.

\section{DESCRIPTION OF STUDY AREA}

The study area is West Windsor Township, Mercer County, New Jersey (fig. 1). Waterquality and water-level data for this study were collected in the vicinity of a 455-acre residential subdivision located between Bear Brook and the Millstone River. Originally called West Windsor Estates I and West Windsor Estates II, the sections of the subdivision currently (1996) are called West Windsor Estates, Kingspoint, Kingspoint East, Brookshyre I, and Brookshyre II. In this report these sections are referred to collectively as the West Windsor Estates subdivision.

\section{Location and Physiography}

West Windsor Township is in northeastern Mercer County, in central New Jersey (fig. 1). The township covers $26.4 \mathrm{mi}^{2}$. The northwestern third of West Windsor Township is in the Piedmont Physiographic Province and southeastern two thirds is in the Coastal Plain (fig. 2). The land surface is relatively flat, with the most relief in areas where streams have carved shallow valleys. The highest land-surface elevation in the township is about $109 \mathrm{ft}$ above sea level. The lowest elevations, about $54 \mathrm{ft}$ above sea level, are where Assunpink Creek in the southwest and the Millstone River in the north leave the township (fig. 1).

\section{Hydrogeologic Setting}

The section of West Windsor Township that lies within the Piedmont Physiographic Province is underlain by Precambrian crystalline rock and the Triassic sandstone and mudstone of the Stockton Formation. In the part of the township that lies within the Coastal Plain, unconsolidated gravel, sand, silt, and clay of Cretaceous and Miocene age crop out. Lithology and hydrologic characteristics of the formations that crop out in the township are given in table 1, and approximate outcrop areas are shown in figure 2 .

Precambrian crystalline rocks composed of metamorphic schist and gneiss are at or near land surface in an area as much as $1 \mathrm{mi}$ wide that trends northeast to southwest. Wells completed in these crystalline rocks can produce water in quantities up to $50 \mathrm{gal} / \mathrm{min}$ from joints and fractures in the rock; however, the average well produces only $12 \mathrm{gal} / \mathrm{min}$, and the crystalline rock is generally a poor aquifer (Widmer, 1965, p. 66). 


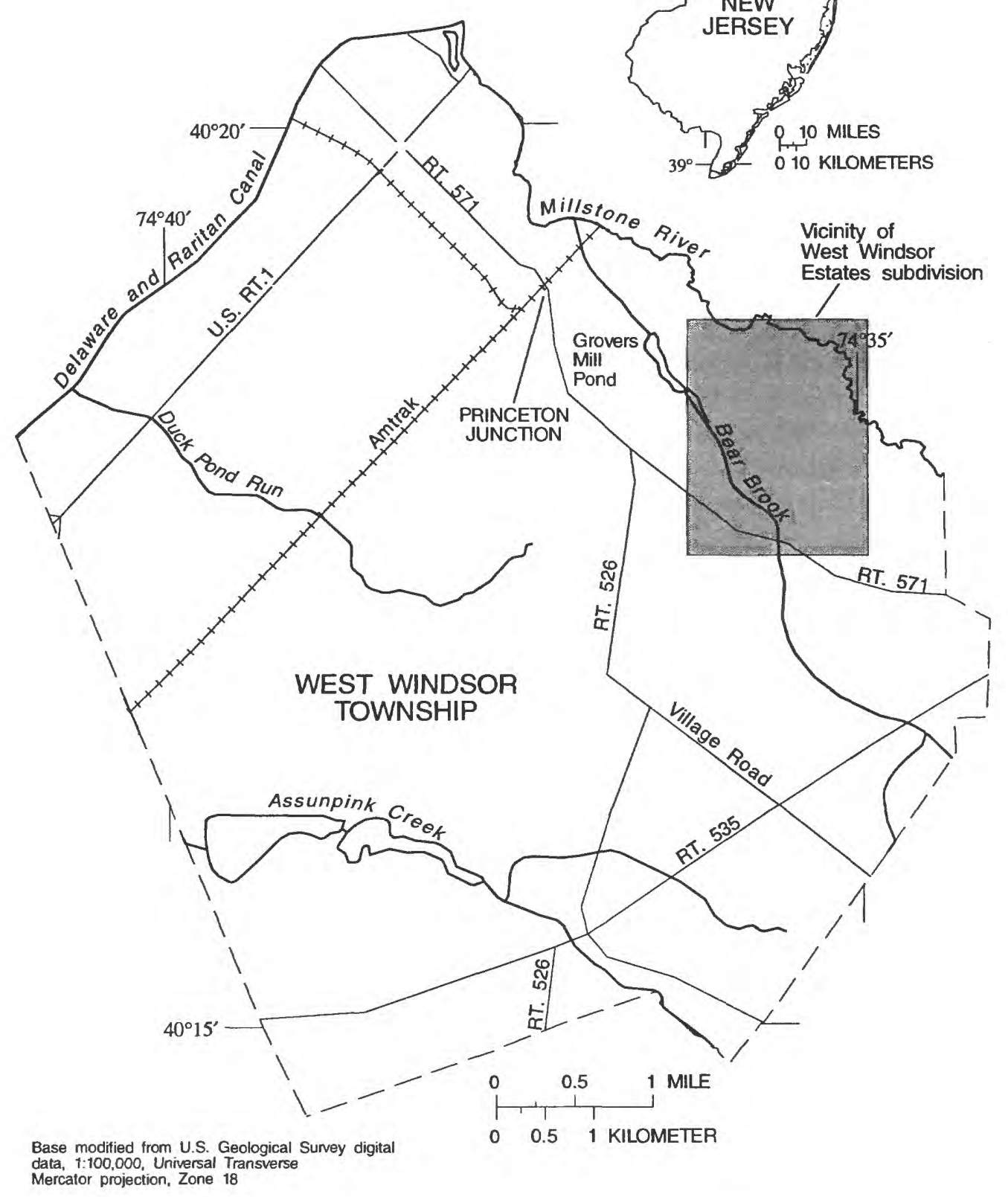

Figure 1. Location of study area, West Windsor Township, Mercer County, New Jersey. 


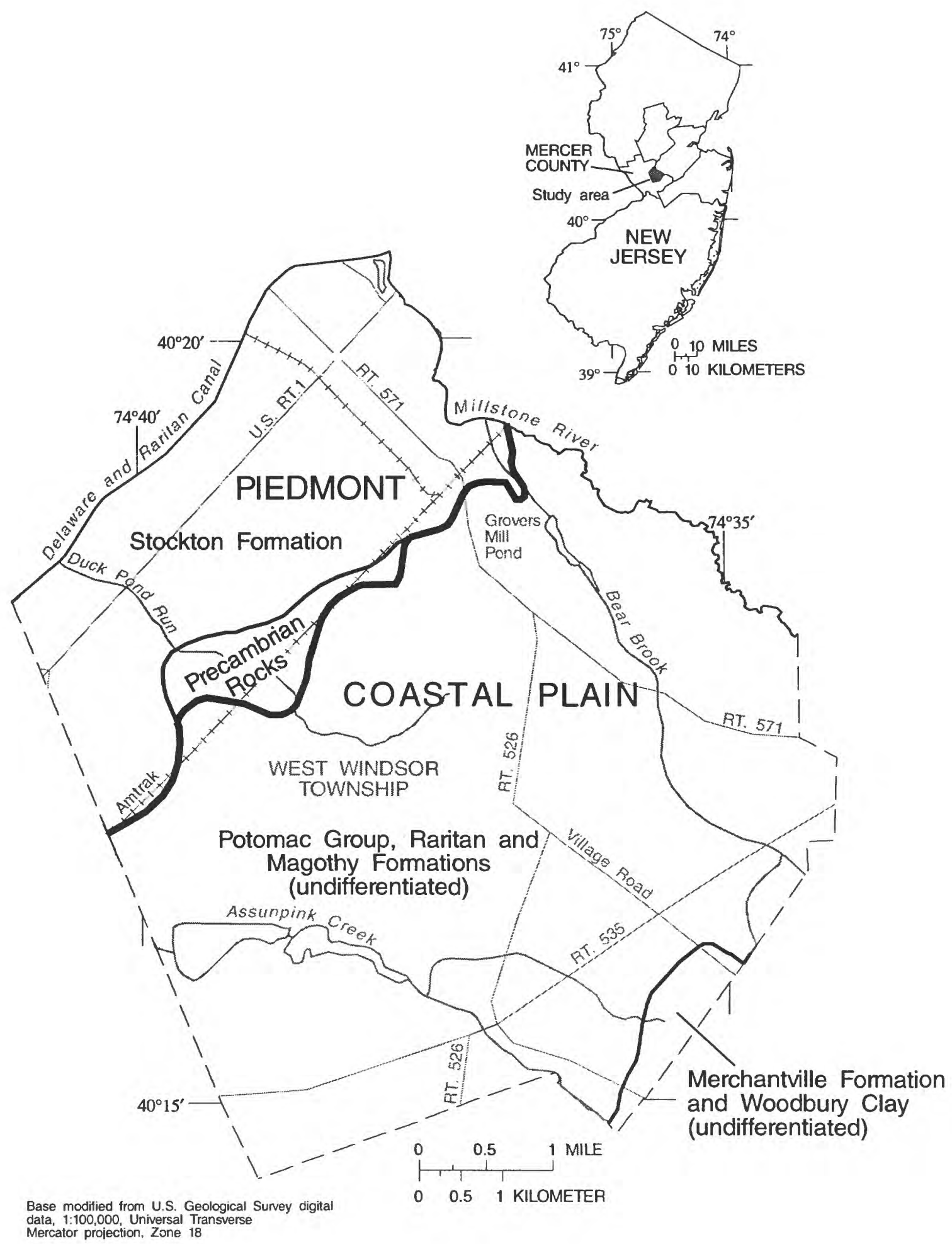

Figure 2. Location of geologic formation outcrops, West Windsor Township, New Jersey. 
Table 1. Geologic and hydrogeologic units, West Windsor Township, New Jersey [Modified from Zapecza, 1989, table 2]

\begin{tabular}{|c|c|c|c|c|}
\hline SYSTEM & $\begin{array}{l}\text { GEOLOGIC } \\
\text { UNIT }\end{array}$ & LITHOLOGY & $\begin{array}{l}\text { HYDROGEO- } \\
\text { LOGIC UNIT }\end{array}$ & $\begin{array}{l}\text { HYDROLOGIC } \\
\text { CHARACTER- } \\
\text { ISTICS }\end{array}$ \\
\hline Miocene & $\begin{array}{l}\text { Bridgeton Forma- } \\
\text { tion }\end{array}$ & $\begin{array}{l}\text { Sand, quartz, iron } \\
\text { stained, heteroge- } \\
\text { neous, clayey, } \\
\text { pebbly }\end{array}$ & Undifferentiated & $\begin{array}{l}\text { Surficial material, } \\
\text { often hydrauli- } \\
\text { cally connected to } \\
\text { Potomac-Raritan- } \\
\text { Magothy aquifer } \\
\text { system }\end{array}$ \\
\hline \multirow[t]{4}{*}{ Cretaceous } & Woodbury Clay & $\begin{array}{l}\text { Gray and black } \\
\text { micaceous silt }\end{array}$ & \multirow[t]{2}{*}{$\begin{array}{l}\text { Merchantville- } \\
\text { Woodbury confin- } \\
\text { ing unit }\end{array}$} & \multirow[t]{2}{*}{$\begin{array}{l}\text { Major confining } \\
\text { unit southeast of } \\
\text { West Windsor } \\
\text { Township }\end{array}$} \\
\hline & $\begin{array}{l}\text { Merchantville } \\
\text { Formation }\end{array}$ & $\begin{array}{l}\text { Clay, glauconitic, } \\
\text { micaceous, gray } \\
\text { and black; locally } \\
\text { very fine-grained } \\
\text { quartz and glauco- } \\
\text { nitic sand }\end{array}$ & & \\
\hline & $\begin{array}{l}\text { Magothy Forma- } \\
\text { tion }\end{array}$ & $\begin{array}{l}\text { Sand, quartz, } \\
\text { light-gray, fine-to } \\
\text { coarse-grained }\end{array}$ & \multirow{2}{*}{$\begin{array}{l}\text { Upper aquifer of } \\
\text { the Potomac-Rari- } \\
\text { tan-Magothy aqui- } \\
\text { fer system } \\
\text { (Old Bridge } \\
\text { aquifer) } \\
\text { Confining unit } \\
\text { Middle aquifer of } \\
\text { the Potomac-Rari- } \\
\text { tan-Magothy aqui- } \\
\text { fer system } \\
\text { (Farrington } \\
\text { aquifer) }\end{array}$} & \multirow{2}{*}{$\begin{array}{l}\text { Major aquifer } \\
\text { southeast of West } \\
\text { Windsor Town- } \\
\text { ship } \\
\text { Major aquifer }\end{array}$} \\
\hline & $\begin{array}{l}\text { Raritan Forma- } \\
\text { tion and Potomac } \\
\text { Group }\end{array}$ & $\begin{array}{l}\text { Sand, quartz, } \\
\text { light-gray, fine- to } \\
\text { coarse-grained, } \\
\text { pebbly, arkosic, } \\
\text { red, white, and } \\
\text { variegated clay }\end{array}$ & & \\
\hline Triassic & $\begin{array}{l}\text { Stockton Forma- } \\
\text { tion }\end{array}$ & $\begin{array}{l}\text { Siltstone, olive- } \\
\text { gray and red, and } \\
\text { fine- to medium- } \\
\text { grained sandstone } \\
\text { with minor } \\
\text { amounts of shale }\end{array}$ & $\begin{array}{l}\text { Stockton Forma- } \\
\text { tion }\end{array}$ & $\begin{array}{l}\text { Locally important } \\
\text { aquifer }\end{array}$ \\
\hline Precambrian & Undifferentiated & $\begin{array}{l}\text { Schist and gneiss, } \\
\text { considered to be } \\
\text { equivalent in age } \\
\text { to the Wissa- } \\
\text { hickon schist }\end{array}$ & Precambrian rocks & $\begin{array}{l}\text { Minor aquifer, low } \\
\text { yield }\end{array}$ \\
\hline
\end{tabular}


The Stockton Formation, a fractured sedimentary-rock aquifer, crops out in the northwestern part of the township (Widmer, 1965, pl. 2), and is the only aquifer present along the Route 1 corridor in the township. Although wells producing an average of $100 \mathrm{gal} / \mathrm{min}$ and as much as $900 \mathrm{gal} / \mathrm{min}$ have been completed in the Stockton Formation (Widmer, 1965, p. 20), withdrawals from this aquifer in West Windsor Township currently (1996) are not extensive.

The Potomac Group and Raritan and Magothy Formations consist of unconsolidated sand, silt, and clay of Cretaceous age, overlie Precambrian and Triassic age rock southeast of the Fall Line, and generally thicken to the southeast. Zapecza (1989, p. B5-B12) and Gronberg and others (1991, p. 5-15) describe the Potomac-Raritan-Magothy aquifer system in detail. In West Windsor Township, the Potomac-Raritan-Magothy aquifer system is composed of two aquifers, the upper aquifer (also called the Old Bridge aquifer) and the middle aquifer (also called the Farrington aquifer). Gronberg and others (1991, pl. 6) show that the upper aquifer attains a thickness of about $25 \mathrm{ft}$ in the township. The middle aquifer is the predominant aquifer in the township, with thicknesses of 50 to more than $80 \mathrm{ft}$ in the south-central part of the township (Gronberg and others, 1991, pl. 3). Overlying the middle aquifer in the southeastern part of the township is a confining unit that ranges in thickness from less than 25 to more than $75 \mathrm{ft}$ (Gronberg and others, 1991, pl. 5)

The Merchantville-Woodbury confining unit, which overlies the Potomac-Raritan-Magothy aquifer system, crops out in a small (less than $1 \mathrm{mi}^{2}$ ) area in the southeastern corner of the township. The Merchantville-Woodbury confining unit is a major confining unit in the south and east, but is not significant in West Windsor Township.

A veneer of Miocene-age sand and gravel of the Bridgeton Formation (Owens and Minard, 1979) and more recent sediments locally overlie the sediments of the Potomac Group and Magothy and Raritan Formations. These sand and gravel deposits are of little hydrologic importance in most areas of the township, but are as much as $100 \mathrm{ft}$ thick in isolated areas in the southeastern part of the township. Where present, these Miocene deposits are typically in hydraulic connection with the underlying aquifer (Widmer, 1965, p. 67).

\section{Land Use and Population}

West Windsor Township is primarily a residential community, but also has agricultural, commercial, and light industrial areas. The heaviest development is along the U.S. Route 1 corridor and in Princeton Junction. During the 1970's, 1980's, and 1990's, many residential subdivisions replaced agricultural land throughout the northern and eastern areas of the township. The southwestern area of the township is less developed and includes research farms of a pesticide and fertilizer manufacturer, and parts of Mercer County Park and Mercer County Community College.

In the 1930's, West Windsor Township was a predominately agricultural community, with livestock, vegetable, and field-crop farms. In 1972, about 9,137 acres in the township were designated as agricultural land for tax purposes (60 percent), of which 7,641 acres were cropland or pasture and 1,496 acres were woodland (New Jersey Division of Taxation, 1973). The acreage designated as agricultural remained relatively constant through 1984, but decreased considerably 
after 1984 because of residential development. By 1991, only 5,808 acres were designated as agricultural land ( 35 percent), of which 4,175 acres were cropland or pasture and 1,633 acres were woodland (New Jersey Division of Taxation, 1992).

Land-use/land-cover data acquired by the Landsat remote sensing satellite on August 23, 1985 , are summarized in table 2 . In residential areas, lawns are classified as agriculture/grassland; houses, driveways, roads, and other impermeable surfaces are classified as urban. Tilled cropland and other disturbed land with significant vegetation are considered agriculture/grassland. Barren land includes disturbed land without significant vegetation, typically areas under construction. Areas classified as barren in 1985 are most likely at present (1996) urban or agriculture/grassland. Although 76 percent of the township is classified as agriculture/grassland or forestland, much of this is residential land with lawns or wooded lots.

Table 2. Area and percentage of land occupied by six land-use/ land-cover types in West Windsor Township, New Jersey, 1985 [From Curtis Price, U.S. Geological Survey, written commun., 1994]

\begin{tabular}{crcc}
\hline $\begin{array}{c}\text { Land-use/ } \\
\text { land-cover } \\
\text { type }\end{array}$ & Acres & $\begin{array}{c}\text { Square } \\
\text { miles } \\
\left(\mathrm{mi}^{2}\right)\end{array}$ & Percentage \\
\hline Urban & 2,500 & 3.9 & 15 \\
$\begin{array}{c}\text { Agriculture/ } \\
\text { grassland }\end{array}$ & 7,200 & 11.2 & 42 \\
Forestland & 5,800 & 9.0 & 34 \\
Water & 300 & 0.5 & 2 \\
Wetlands & 100 & 0.2 & 1 \\
Barren & 1,000 & 1.6 & 6 \\
Total & 16,900 & 26.4 & 100 \\
\hline
\end{tabular}

The 1990 population of West Windsor Township was 15,799 (U.S. Bureau of the Census, 1991). The 1990 average population density, calculated by dividing total population by area (26.4 $\mathrm{mi}^{2}$ ), was 598 people per square mile. Population from 1930 to 1990 is shown in figure 3 . The population of the township increased by 1,500 to 2,500 people per decade from 1930 to 1980 . From 1980 to 1990 , however, the population of the township increased by 7,250 people because many farms were subdivided and developed for residential use.

\section{Public Water Supply and Sewer Systems}

Elizabethtown Water Company currently provides water for public use to residences and businesses in most areas of West Windsor Township. Elizabethtown Water Company draws most of its water from intakes in the Delaware and Raritan Canal and the Millstone River about 15 miles north of West Windsor Township. In West Windsor Township and vicinity, however, the water company supplements the surface-water supply with about $1.2 \mathrm{Mgal} / \mathrm{d}$ from two wells 


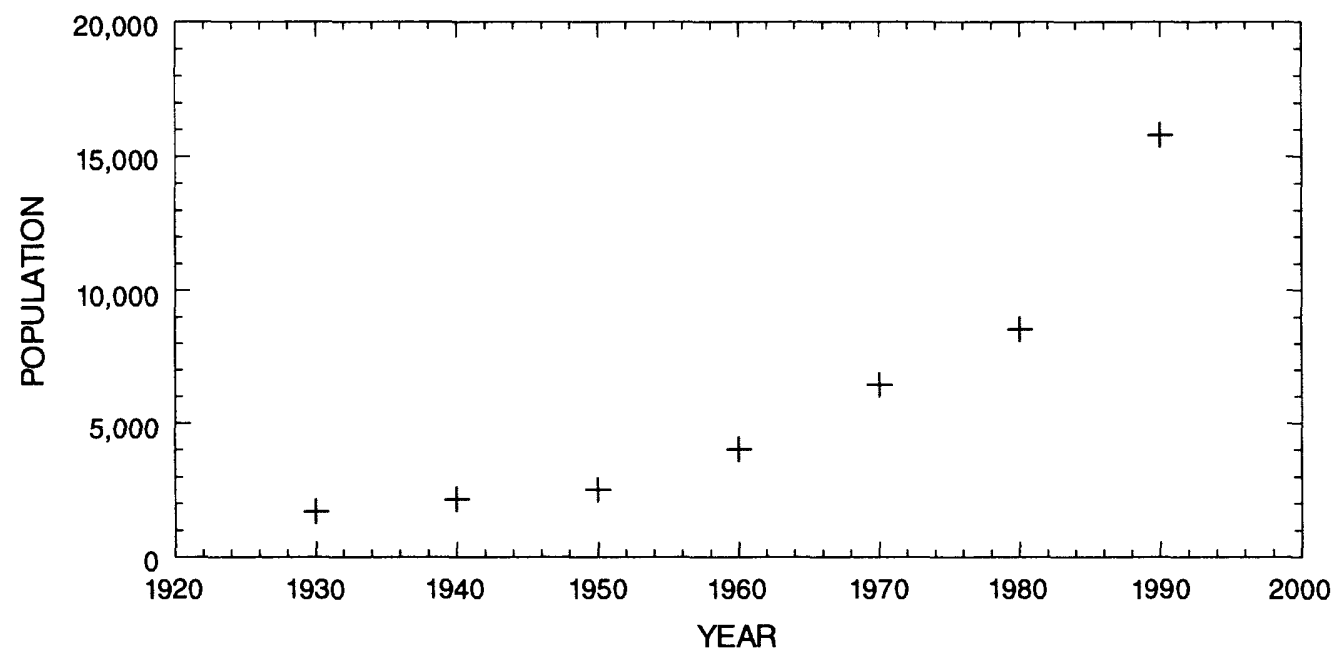

Figure 3. Population of West Windsor Township, New Jersey, 1930-90.

completed in the Farrington aquifer (wells 21-120 and 21-122; fig. 4) and, in summer, about 0.7 $\mathrm{Mgal} / \mathrm{d}$ from seven wells completed in the Stockton Formation (including wells 21-165, 21-196, 21-205, and 21-247; fig. 4) (Richard Sadowski, Elizabethtown Water Company, oral commun., 1994). Water-quality data for wells $21-122,21-165,21-196,21-205$, and 21-247 are listed in table 3.

Sewers were first installed in the township in 1979. At that time, sewer lines were laid in Princeton Junction, and over the next few years were extended to outlying developments. Prior to 1979, all residences had septic systems except for a few hundred residences and several businesses that were served by nine small, private sewage-treatment plants (Bergman Hatton Associates, 1992, p. 3). During the 1980's, some of the new residences were connected to the sewer system, but many were built with public water-supply and on-site septic systems. In 1993, about 3,925 residences and 225 businesses were connected to the sewer system and about 2,475 residences had on-site septic systems, indicating that about 40 percent of the population was served by on-site septic systems. Sewered areas of the township served by the Stony Brook Regional Sewage Authority or Hamilton Township Water Pollution Control and unsewered areas with private septic systems are shown in figure 4.

\section{Historical Nitrate Concentrations in Ground Water}

Nitrate is present in water samples from most wells in West Windsor Township. In 1958, Vecchioli and Palmer (1962, p. 70-71) collected ground-water samples in the township and reported concentrations of nitrate as nitrogen at $27 \mathrm{mg} / \mathrm{L}$ in samples from a shallow well screened in Coastal Plain sediments and at $15 \mathrm{mg} / \mathrm{L}$ in samples from a shallow well completed in the Stockton Formation. (Nitrate as nitrogen is hereafter referred to as nitrate.) These results indicate that nitrate concentrations in some ground water in West Windsor Township have exceeded the $\mathrm{MCL}$ of $10 \mathrm{mg} / \mathrm{L}$ since at least 1958 . The areal distribution of nitrate in ground-water samples 


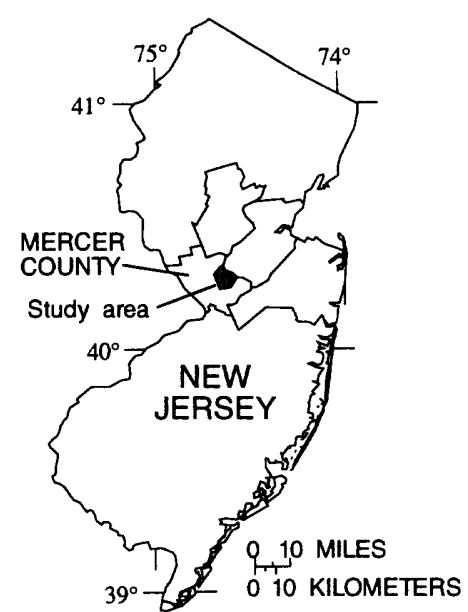

\section{EXPLANATION}

- PUBUC SUPPLY WEU -- Number is U.S. Geological Survey well number

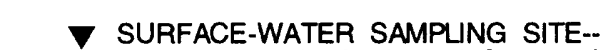
01400650 Number is U.S. Geological Survey site number

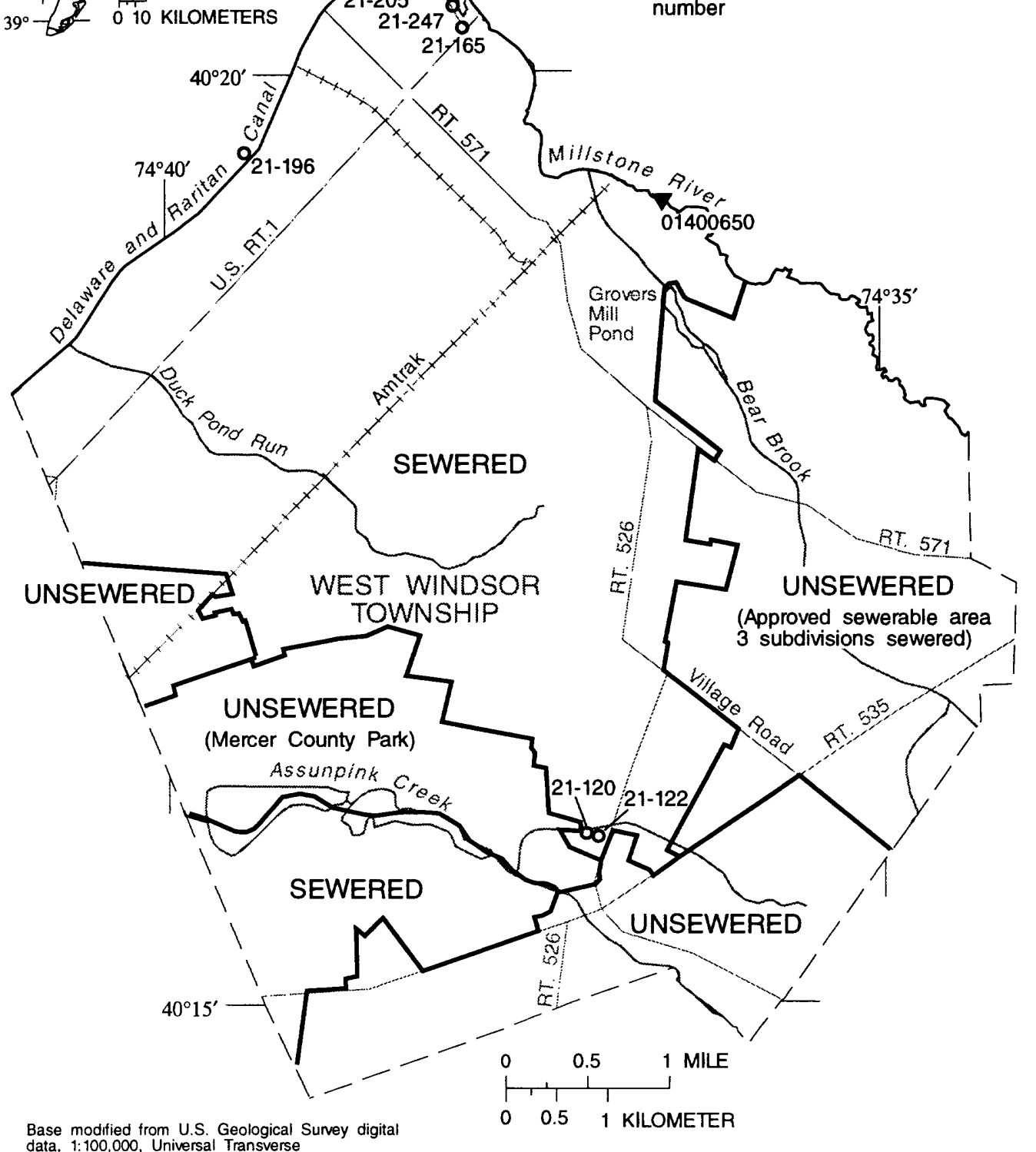

Base modified from U.S. Geological Suney digital data, 1:100,000, Universal Transverse

Mercator projection, Zone 18

Figure 4. Location of sewered and unsewered areas and public supply wells in West Windsor Township, New Jersey. (Sewer data from sewer system map, West Windsor Township, November 1992, scale 1:24,000) 


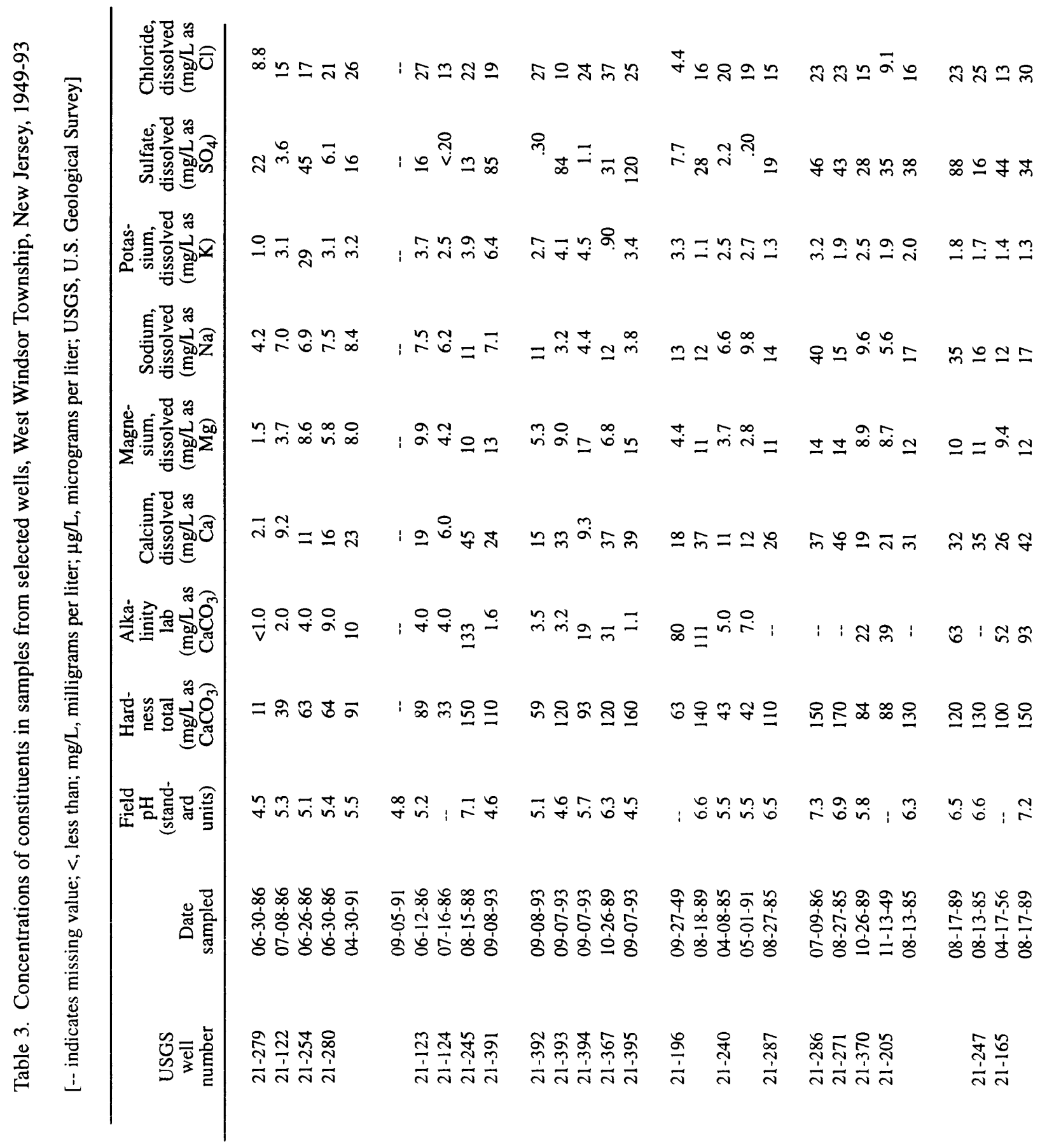




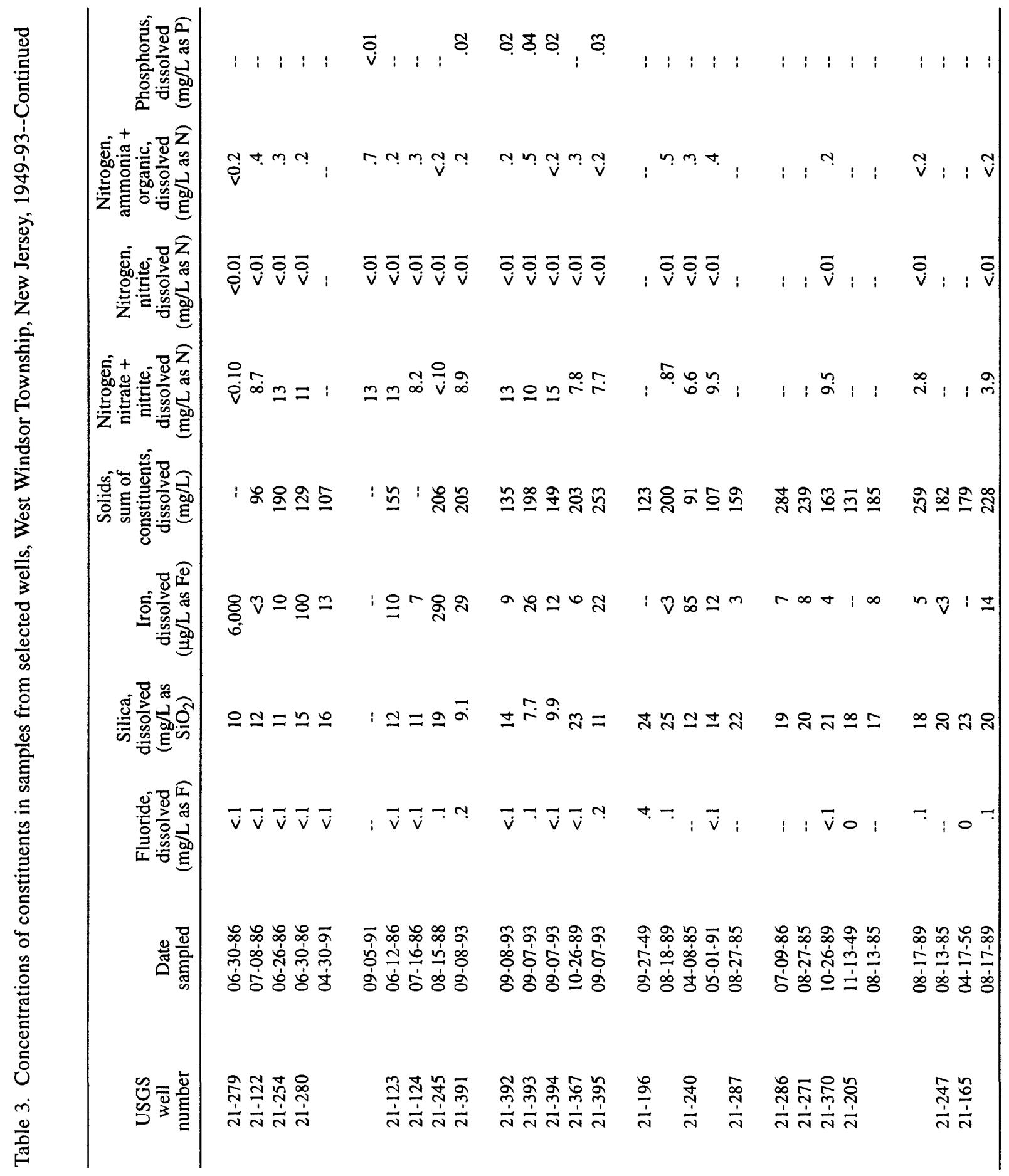


collected during 1985-93 is shown in figure 5. Data shown are from the USGS water-quality data base, Murphy (1992), and Robert Hary and Sharon Black (West Windsor Township Health Department, written commun., 1994). Additional ground-water-quality data for selected wells sampled by the USGS are listed in table 3.

Eighteen ground-water samples collected by the USGS during 1985-93 were analyzed for nitrate (fig. 5 and table 3). Concentrations of nitrate ranged from less than 0.1 to $15 \mathrm{mg} / \mathrm{L}$. The median concentration was about $8.5 \mathrm{mg} / \mathrm{L}$, the same as the median concentration in samples collected from shallow wells completed in the Potomac-Raritan-Magothy aquifer system and located in agricultural areas (Vowinkel and Battaglin, in press). The median concentration of nitrate was about $8 \mathrm{mg} / \mathrm{L}$ in samples from six domestic wells, and about $4 \mathrm{mg} / \mathrm{L}$ in samples from four public supply wells. The concentration of nitrate in a sample from the one irrigation well was $13 \mathrm{mg} / \mathrm{L}$. The concentrations of nitrate typically were greater in water from wells screened in the Coastal Plain aquifers (median about $10 \mathrm{mg} / \mathrm{L}$ ) than in water from wells open to the bedrock aquifers (median about $3 \mathrm{mg} / \mathrm{L}$ ). Eleven of the 12 wells sampled in the Potomac-Raritan-Magothy aquifer system are less than $100 \mathrm{ft}$ deep. Although four of the six wells open to bedrock aquifers are more than $100 \mathrm{ft}$ deep, the open interval of each well begins at a depth of $50 \mathrm{ft}$ or less; therefore, samples include water from shallow depths.

Murphy (1992) collected water samples during spring 1990 from 17 domestic wells in West Windsor Township, 16 of which are screened in the Potomac-Raritan-Magothy aquifer system. The samples contained concentrations of nitrate ranging from less than 0.1 to $9.5 \mathrm{mg} / \mathrm{L}$; the median was about $6 \mathrm{mg} / \mathrm{L}$. Most wells were screened at depths less than $100 \mathrm{ft}$ below the land surface. Water from three of the four wells with depths greater than $100 \mathrm{ft}$ contained concentrations of nitrate less than the detection limit of $0.1 \mathrm{mg} / \mathrm{L}$.

Robert Hary and Sharon Black (Written commun., 1994) reported concentrations of nitrate in samples collected from 13 domestic wells during 1989-92. (Data were retrieved from files at the West Windsor Township Health Department.) Concentrations of nitrate in samples ranged from less than 0.01 to $12 \mathrm{mg} / \mathrm{L}$ with a median concentration of about $6 \mathrm{mg} / \mathrm{L}$. The concentration of nitrate in samples from two wells exceeded the MCL, but the concentration of nitrate was considerably below the MCL when the wells were resampled approximately 2 weeks later, possibly after a water-treatment system was installed. For these two wells, the higher values (11.1 and $11.2 \mathrm{mg} / \mathrm{L}$ ) are shown on figure 5 . The exact locations and depths of the wells reported by Hary and Black are not known; therefore, in figure 5 the wells are plotted in the center of the block and lot of the well owner's land.

The elevated concentrations of nitrate (greater than $1 \mathrm{mg} / \mathrm{L}$ ) in ground water throughout West Windsor Township are the result of human activities. The median concentration of nitrate in samples from wells screened in Coastal Plain sediments is higher than that of wells open to Piedmont rocks, most likely because of the higher density of agricultural land use in the Coastal Plain. Although about half the agricultural land present in 1972 was converted to residential and other uses by 1991, nitrate in ground water underlying formerly agricultural land can persist for years. Residential land use, however, is also a source of nitrate, and some of the nitrate present in ground water underlying residential areas is the result of current land use. To investigate the effect on water quality of converting from agricultural to residential land use, ground-water samples were collected in a residential subdivision built on formerly agricultural land and analyzed. 


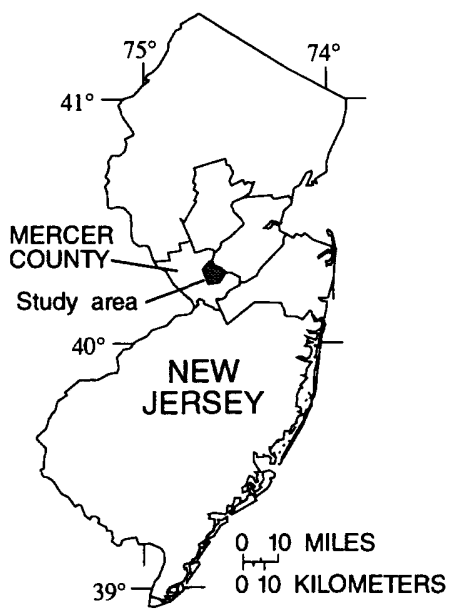

EXPLANATION

WELL--Upper number is U.S. Geological Survey well number (appendix 1). Lower number is $21-370^{\circ}$ concentration of nitrate as nitrogen in milligrams per liter (table 3). Data from U.S. Geological Survey data bases

6.04 WEL--Number is concentration of nitrate in milligrams per liter. Data from Murphy (1992)

WELL-Number is concentration of nitrate in $1.1^{\ominus}$ milligrams per liter. Data from Hary and Black (West Windsor Township Health Department, written commun. 1994)

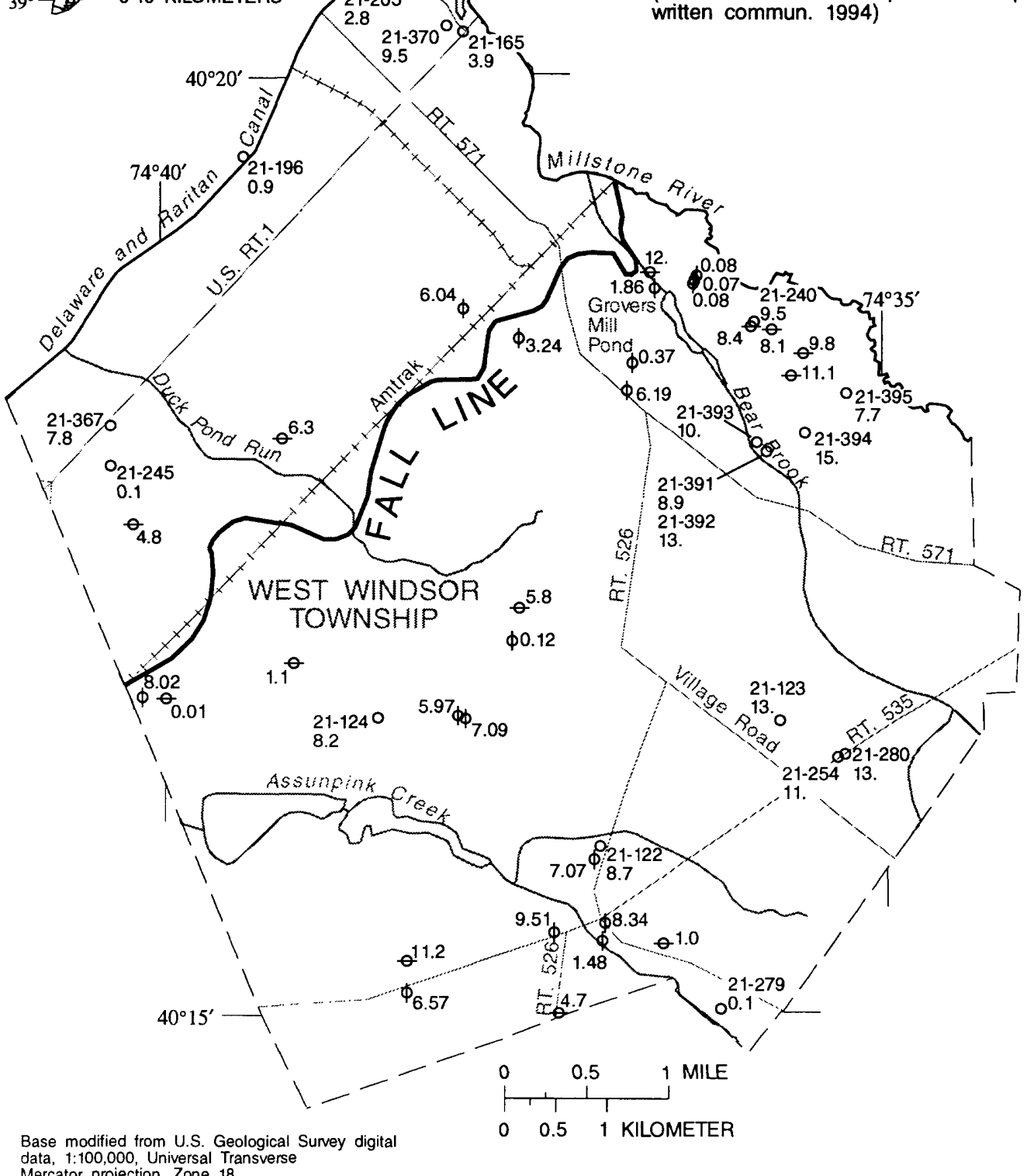
data, 1:100,000, Universal Transverse Mercator projection, Zone 18

Figure 5. Concentrations of nitrate as nitrogen in water samples from selected wells, West Windsor Township, New Jersey, 1985-93. 


\section{NITRATE IN GROUND WATER AND SURFACE WATER IN A RESIDENTIAL SUBDIVISION}

The West Windsor Estates subdivision covers 455 acres that were previously agricultural land and wetland. Prior to the start of construction in the mid-1980's, the land was farmed for potatoes and grains (Samuel Surtees, West Windsor Township Planning Department, written commun., 1994). The subdivision has 371 housing lots that average 0.75 acres each. Construction of sections of the subdivision was completed in stages, the last of which was completed in 1996. West Windsor Township has an average of 3.3 people per residence; therefore, the estimated population density for the West Windsor Estates subdivision is 1,225 people per 455 acres or 870 people/mi ${ }^{2}$. All residences in the West Windsor Estates subdivision are served by public watersupply and on-site septic systems.

\section{Ground Water}

In 1989, the West Windsor Township Environmental Commission had five wells installed in the West Windsor Estates subdivision while the subdivision was under construction. The purpose of the wells was to monitor ground-water levels and ground-water quality (fig. 6). Geologic logs of these wells (BCM Engineers, Inc., 1989) indicate that all five wells were completed in silty or gravelly sands that are orange-yellow, orange-brown, or yellow-brown in color. The color of the sediments indicates that all five wells are screened in the Bridgeton Formation, which is considered to be hydraulically connected to the Potomac-Raritan-Magothy aquifer system (Farrington aquifer) at this location. Wells MW-1 (21-394), MW-2 (21-395), MW-3 (21-391), and MW-5 (21-393) (fig. 5) are screened near the water table. MW-4 (21-392), located adjacent to MW-3, is screened about 25 to $35 \mathrm{ft}$ below the water table. Well-construction and -location information is listed in appendix 1 . Measured water levels are listed in table 4 , and selected waterquality data are listed in table 3.

Water levels differ by less than $0.7 \mathrm{ft}$ in wells MW-2, MW-3, MW-4, MW-5, and at a staff gage in an irrigation pond adjacent to wells MW-3, MW-4, and MW-5 (table 4). Ground water flows from areas of higher head to lower head; therefore, these water levels show that ground water flows southwest from MW-2, discharging to the irrigation pond and Bear Brook. Although MW-1 is located near the topographic divide between Bear Brook and the Millstone River, the water-level altitude in MW-1 is 1.6 to $2.3 \mathrm{ft}$ lower than in the other wells, indicating that MW-1 is on the opposite side of a ground-water divide from MW-3, MW-4, and MW-5. The ground-water divide is located near MW-2; therefore, most of the recharge to the ground-water system from precipitation and septic systems in the West Windsor Estates subdivision is discharging to the Millstone River. Public water delivered to homes in the West Windsor Estates subdivision is from sources outside the immediate watershed but is discharged into on-site septic systems and lawns. The net importation of water into the area may have caused the water table to rise locally, but no pre-1993 water-level data are available; therefore, trends in long-term recharge could not be determined.

Differences in nitrate concentrations in ground water over a 55-month period were investigated by sampling five wells in the West Windsor Estates subdivision. Ground-water samples were collected in February 1989 and May 1989 by BCM Engineers, Inc., (1990, p.9-10) 


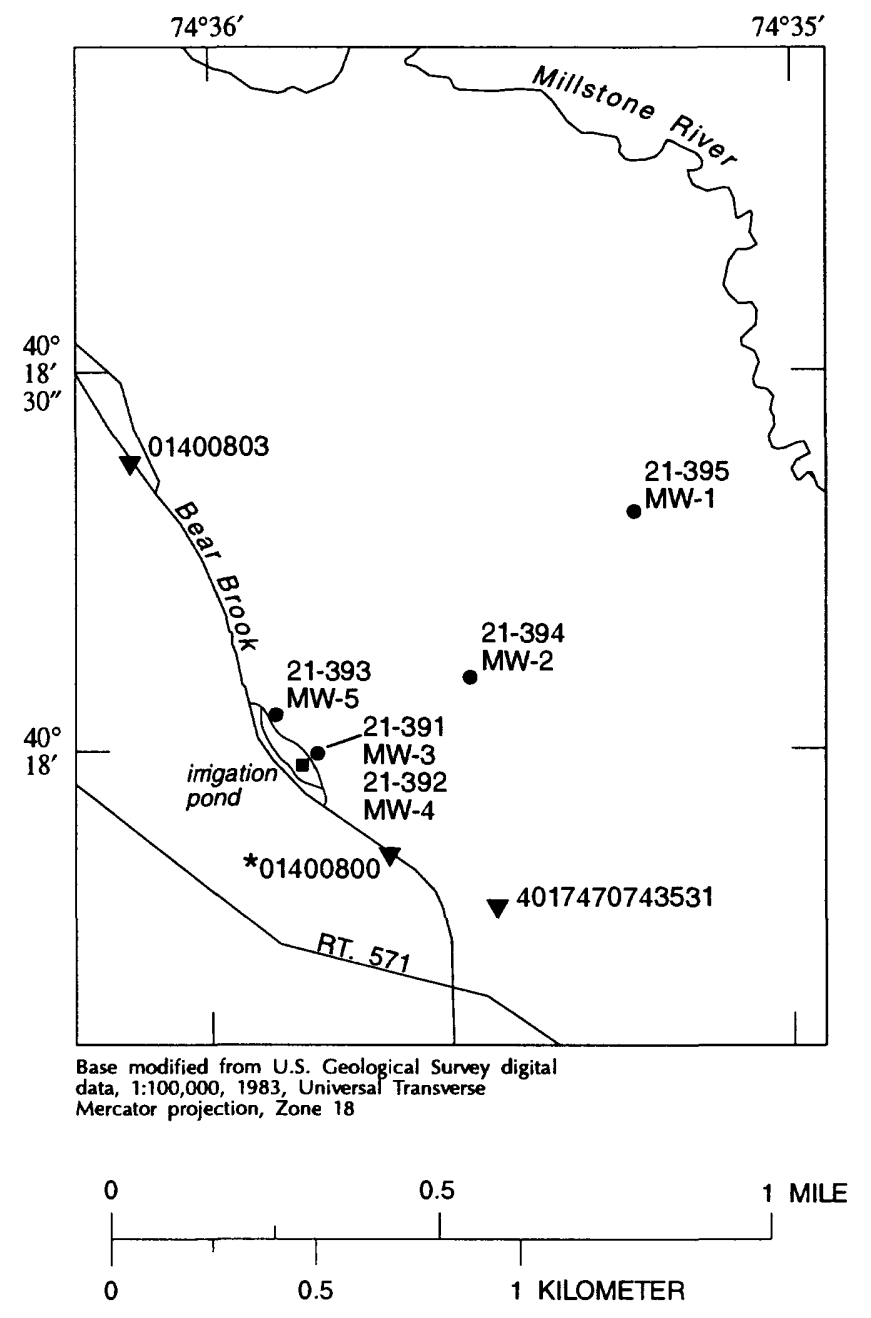

\section{EXPLANATION}

21-395 MONITORING WELL--Number is U.S. Geological -MW-1 Survey well number. "MW-1" is well name

SURFACE-WATER SAMPLING SITE--Number is site identification number. * identifies site with a pemanent staff gage

- TEMPORARY STAFF GAGE

Figure 6. Location of five wells, two staff gages, and three surfacewater-quality sampling sites in the vicinity of the West Windsor Estates subdivision, West Windsor Township, New Jersey. 


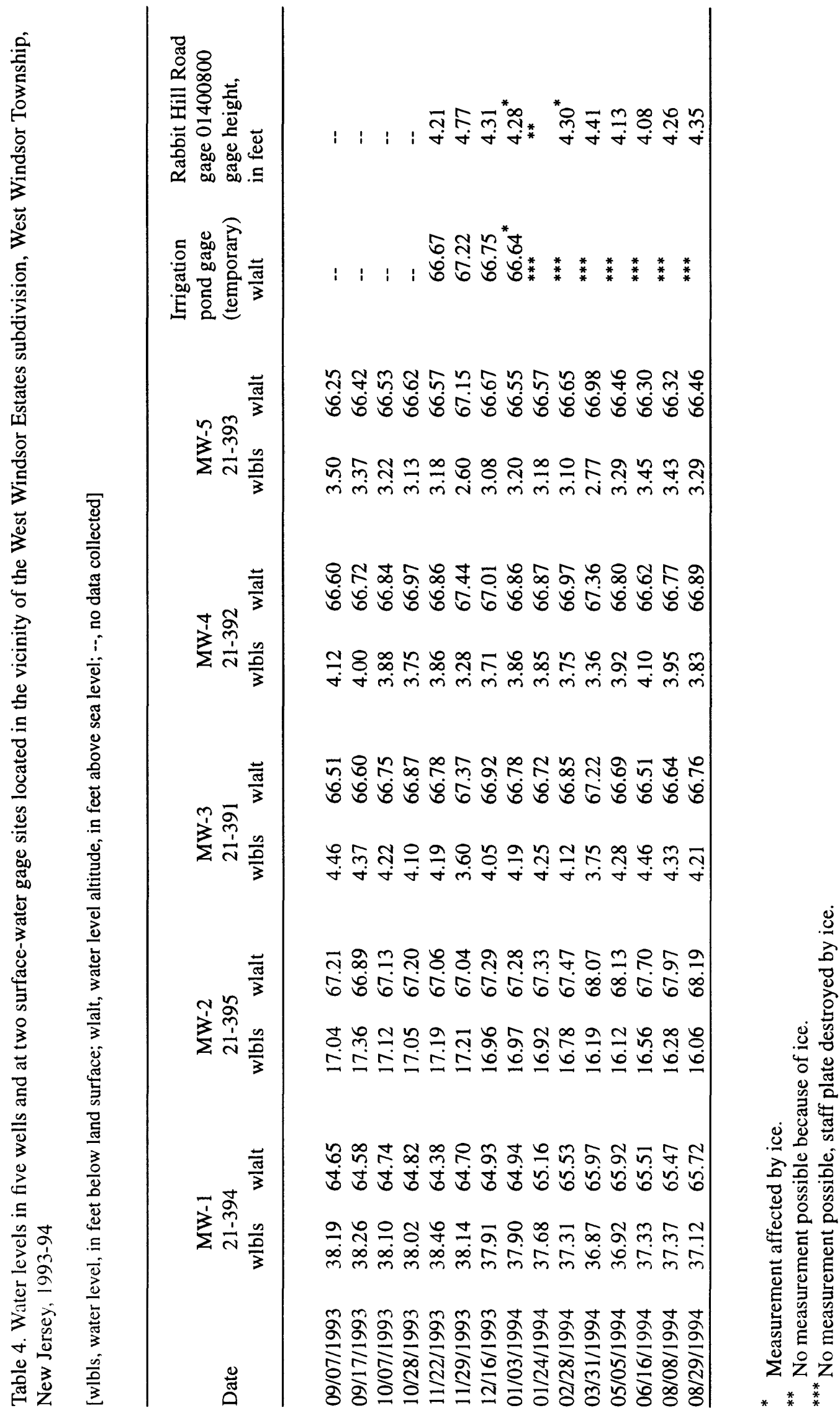


and in September 1993 by the USGS (fig. 7). (USGS water-quality data for the five wells are listed in table 3.) The median concentration of nitrate in samples from the five wells decreased over the sampling period. The median concentration of nitrate was $15 \mathrm{mg} / \mathrm{L}$ in February 1989, 13 $\mathrm{mg} / \mathrm{L}$ in May 1989, and $10 \mathrm{mg} / \mathrm{L}$ in September 1993. The 23-percent decrease in the median nitrate concentration from May 1989 to September 1993 indicates that the change from agricultural to residential land use could have led to a decrease in nitrate concentration in ground water. A definite conclusion cannot be reached from these data because the sampling took place during different seasons; the samples were collected 3 months and 52 months apart, respectively; and the samples were collected and analyzed by different organizations. In addition, during 198993 the land was not used for agriculture; however, nitrate loading from residential land was not at the maximum rate because construction of homes was ongoing. The full nitrate loading from residential land did not occur until all the homes were constructed and occupied and lawns planted in 1996. Additional data are needed to confirm the downward trend in nitrate concentrations in ground water.

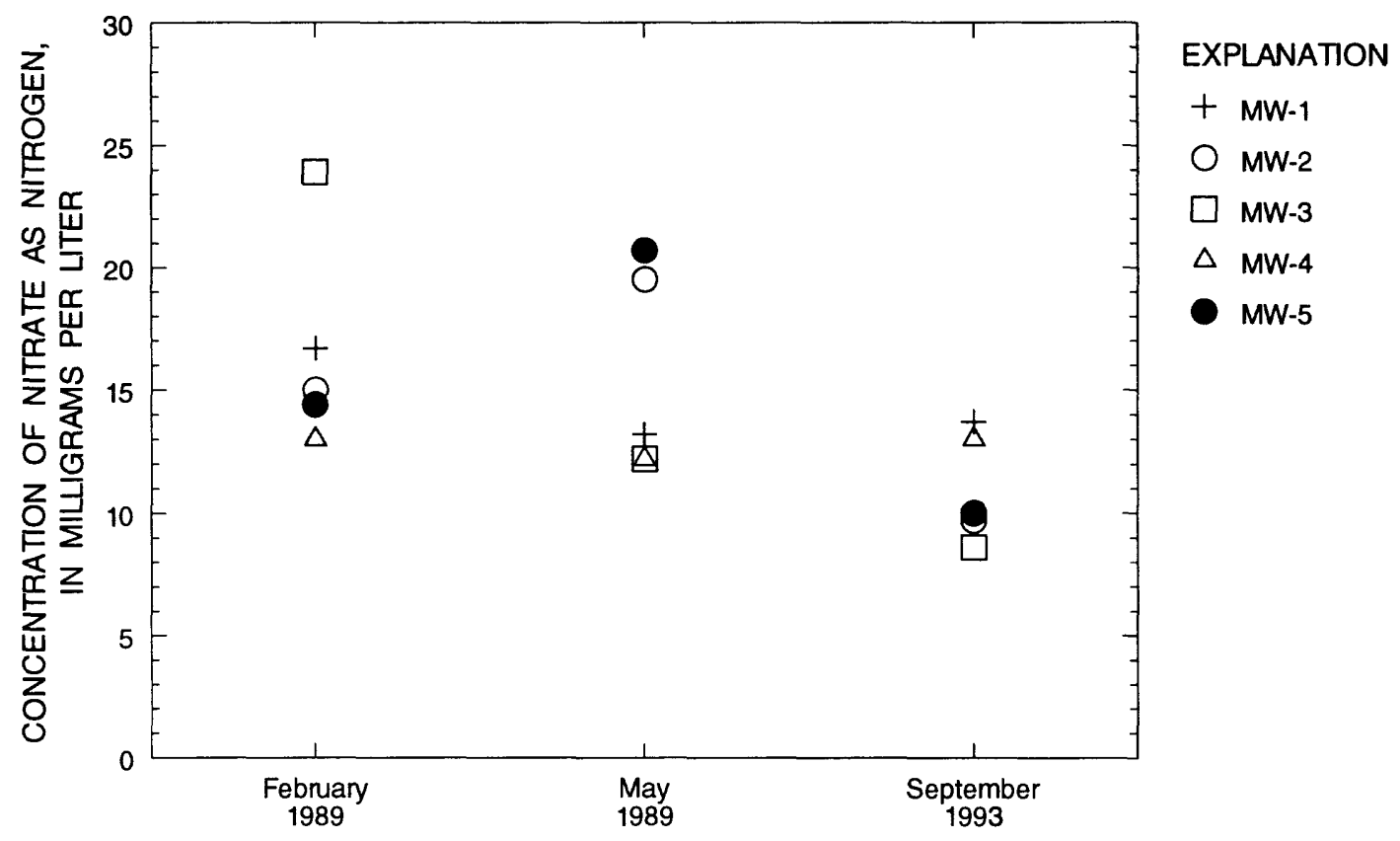

SAMPLING EVENT

Figure 7. Concentrations of nitrate as nitrogen in samples from five wells in the West Windsor Estates subdivision, West Windsor Township, New Jersey, February 1989, May 1989, and September 1993. 


\section{Surface Water}

The concentrations of nitrate in samples collected at sites 01400800 and 01400803 on Bear Brook on October 19, 1993, (fig. 6) during base-flow conditions were 4.6 and $3.7 \mathrm{mg} / \mathrm{L}$, respectively (table 5). These concentrations are similar to the median concentration of nitrate in 11 samples (3.9 mg/L) collected during 1975-93 from the Millstone River at Grovers Mill (fig. 4). (Data are from the U.S. Geological Survey water-quality data base maintained in West Trenton, N.J. Concentrations of nitrate and other constituents in surface-water samples collected during 1993 are listed in table 5.) No point sources of nitrate, such as sewage-treatment-plant discharge, are present on Bear Brook; therefore, the significant concentration of nitrate present in base-flow samples indicates that nitrate is being transported to the brook by ground water. If the apparent downward trend of nitrate concentrations in ground water in the vicinity continues, nitrate concentrations in Bear Brook could decrease.

Stormwater runoff can contain elevated concentrations of nitrate or other contaminants; therefore, the role of revegetated stormwater detention basins in removing contaminants was investigated. Stormwater detention basins are designed to attenuate flood peaks on streams by storing runoff for 2 to 24 hours, releasing the water through an engineered outlet (New Jersey Department of Environmental Protection and Energy, 1989). Detention basins can improve stormwater-runoff quality by acting as a settling basin, allowing suspended sediment to settle out of the runoff. In addition, some dissolved constituents, such as certain organic compounds, can sorb to soil or plant materials in the basin. Because of the short residence time, however, plants (or other mechanisms) have little opportunity to remove dissolved constituents from the runoff. A stormwater infiltration basin (retention basin) that is designed to hold water until the water can infiltrate into the ground and reach the water table can act to improve surface-water quality. As water infiltrates, plant roots can take up significant amounts of dissolved nitrate in a matter of hours (Jacob Gibs, U.S. Geological Survey, written commun., 1994), and ammonium and organic nitrogen will readily sorb to the soil particles.

Most stormwater basins in West Windsor Township, including the basins in the West Windsor Estates subdivision, were designed as detention basins, not infiltration basins. To measure the effectiveness of a revegetated stormwater detention basin (site 401747074353101; fig. 6) in removing dissolved nitrogen species from stormwater runoff, a shallow well was installed in the basin floor to sample water percolating to the water table from the basin. The well, screened from 7 to $9 \mathrm{ft}$ below land surface, could not be sampled because it did not yield any water when pumped, indicating that the sediments below the basin floor are relatively impermeable. These low-permeability sediments preclude the infiltration of significant quantities of water from the basin; therefore, little or no dissolved nitrogen species are removed from stormwater runoff before the runoff enters the stream.

A sample of stormwater runoff was collected from the detention basin (site 401747074353101) on November 28, 1993, after 2.2 in. of rain had fallen, to measure the concentration of nitrogen species in stormwater runoff. The sample was collected 2 to 4 weeks after lawn services in the area had applied the last seasonal application of fertilizer (Lawn Doctor of Mercer County, oral commun., 1993). No significant precipitation occurred in the 3 weeks preceding the storm of November 27-28; therefore, detectable concentrations of nitrogen species in the runoff were 


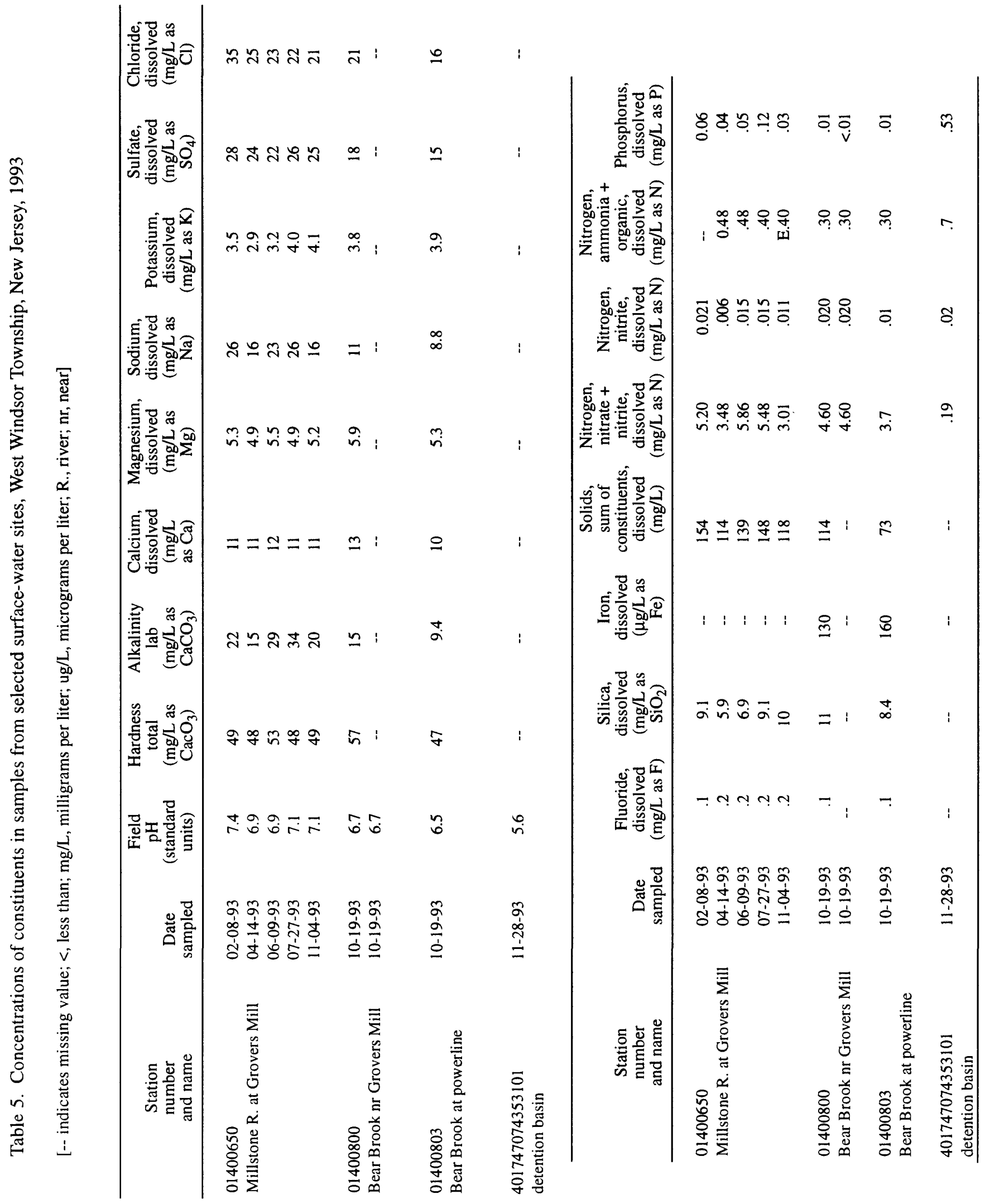


expected. The concentration of nitrate in the sample was $0.19 \mathrm{mg} / \mathrm{L}$ and the total concentration of nitrogen species measured was $0.89 \mathrm{mg} / \mathrm{L}$ (table 5). The volume-weighted average nitrate concentration in precipitation that fell at Washington Crossing, N.J., (about 15 miles west of West Windsor Township) in 1992 (0.26 mg/L; National Atmospheric Deposition Program, 1993) however, was greater than the concentration in the stormwater-runoff sample, indicating that the runoff sample contained little or no nitrate from the lawns. The total dissolved nitrogen concentration apparently includes nitrogen from the lawns, but additional samples would be necessary to confirm this.

\section{Estimated Nitrate Concentrations in Ground-Water Recharge From Residential Land}

Before the 1980's, nitrate in ground water and surface water in the West Windsor Estates subdivision came primarily from nitrogen-rich agricultural fertilizers, either organic or chemical. Current (1996) major sources of nitrate are septic systems and lawn fertilizers. Low, medium, and high estimates of the nitrate concentrations in ground-water recharge from septic-system effluent and fertilized lawns in the West Windsor Estates subdivision were calculated by using data collected for this study and data from other studies. If the medium estimate is accurate, the nitrate concentration in shallow ground water underlying the subdivision could decrease slightly over a period of years.

\section{Nitrate from Septic Systems}

Low, medium, and high estimates of the concentrations of nitrate in ground-water recharge from septic systems in the West Windsor Estates subdivision are $2 \mathrm{mg} / \mathrm{L}, 4 \mathrm{mg} / \mathrm{L}$, and $7 \mathrm{mg} / \mathrm{L}$, respectively. The equations and individual components used to estimate these concentrations are listed in table 6. Low, medium, and high estimates for each component were used to determine the approximate range of concentrations.

The nitrate concentration in recharge to ground water from septic systems in the West Windsor Estates subdivision was calculated by using estimates of septic-system discharge rate, nitrate concentration in septic-system effluent, denitrification rate, and ground-water recharge rate from precipitation. Frimpter and others (1988, p. A3) estimated domestic septic-system discharge to be from 50 to 70 gallons per day per person. The population of the West Windsor Estates subdivision was estimated by multiplying the number of residences (371) by the average occupancy (3.3 people per house) (Samuel Surtees, written commun., 1994).

Pucci and others (1994, p. 76) estimated the average ground-water recharge from precipitation in the Potomac-Raritan-Magothy aquifer system to be about $15 \mathrm{in} / \mathrm{yr}$, although other sources use estimates of $20 \mathrm{in} / \mathrm{yr}$ (Pucci and others, 1994, p. 58). BCM Engineers, Inc., (1990, p. 42) estimated recharge to be $14 \mathrm{in} / \mathrm{yr}$. 
Table 6. Low, medium, and high estimates of concentrations of nitrate in ground-water recharge from septic systems, West Windsor Estates subdivision, West Windsor Township, New Jersey, and parameters and equations used to calculate estimates

[gal/d, gallons per day; gal, gallons; $\mathrm{ft}^{3} / \mathrm{yr}$, cubic feet per year; in $/ \mathrm{yr}$, inches per year; $\mathrm{ft}^{2}$, square feet; $\mathrm{ft} / \mathrm{in}$., feet per inch; $\mathrm{mg} / \mathrm{L}$, milligrams per liter; $\mathrm{N}$, nitrogen]

H. Concentration of nitrate as $\mathrm{N}$ in septic-system effluent after nitrification and denitrification $(\mathrm{mg} / \mathrm{L})$

I. Estimated concentration of nitrate as $\mathrm{N}$ in ground-water

recharge from septic systems $(\mathrm{mg} / \mathrm{L})$, where I = G x H
A. Volume of septic-system effluent per person (gal/d)
B. Number of people per house
C. Number of houses in subdivision
D. Total volume of septic-system effluent $\left(\mathrm{ft}^{3} / \mathrm{yr}\right)$, where $\mathrm{D}=\mathrm{A} \times \mathrm{B} \times \mathrm{C} \times\left(1 \mathrm{ft}^{3} / 7.48 \mathrm{gal}\right) \times$ (365 days/year)
E. Ground-water recharge from precipitation (in/yr)
F. Volume of ground-water recharge $\left(\mathrm{ft}^{3} / \mathrm{yr}\right)$, where $F=E \times(455$ acres $) \times\left(43,560 \mathrm{ft}^{2} /\right.$ acre $) \times(1 \mathrm{ft} / 12 \mathrm{in})$
G. Dilution factor of septic-system effluent (dimensionless), where $G=D /(D+F)$

50

3.0

371

$2.72 \times 10^{6}$

20

17

15

$3.30 \times 10^{7}$

$2.81 \times 10^{7}$

$2.48 \times 10^{7}$

.076

.113

.155

25

35

45

2

4

70

3.6

371

$4.56 \times 10^{6}$

2


Estimates of the concentrations of nitrate in effluent leaving septic-system leaching fields range from 30 to $50 \mathrm{mg} / \mathrm{L}$ (U.S. Environmental Protection Agency, 1980), 30 to $35 \mathrm{mg} / \mathrm{L}$ (Frimpter and others,1988, p. A3), and $40 \mathrm{mg} / \mathrm{L}$ (Hantzsche and Finnemore 1992, p. 492). Ammonium and organic nitrogen are the dominant species of nitrogen leaving a typical anaerobic septic tank, but these species are subsequently converted to nitrate by the nitrification process in the aerobic environment of the leaching field. Denitrification, a biological or chemical reduction of nitrate to volatile gases, reduces the concentration of nitrate reaching the water table. Walker and others (1973a, 1973b) found denitrification to be an insignificant nitrate-removal mechanism in unsaturated sandy soils, but Hantzsche and Finnemore (1992, p. 491) estimated that 10 to 25 percent of nitrate from septic systems is removed by denitrification. The concentration of nitrate in septic-system effluent after nitrification and denitrification in the West Windsor Estates subdivision is estimated to be from 25 to $45 \mathrm{mg} / \mathrm{L}$.

\section{Nitrate from Lawn Fertilizers}

Low, medium, and high estimates of the concentrations of nitrate in ground-water recharge containing nitrate from lawn fertilizers in the subdivision are $0.5 \mathrm{mg} / \mathrm{L}, 3 \mathrm{mg} / \mathrm{L}$, and $7 \mathrm{mg} / \mathrm{L}$, respectively. The equations and individual components used to estimate these concentrations are listed in table 7. Low, medium, and high estimates for each component were used to determine the approximate range of concentrations.

The range of concentrations of nitrate in ground-water recharge from lawn fertilizers was calculated from estimated fertilizer-application rates, the percentage of applied fertilizer leaching from lawns, total lawn area in the subdivision, and the ground-water recharge rate from precipitation.

Average fertilizer-application rates in West Windsor Township were estimated from questionnaires mailed to all township residents by the West Windsor Township Environmental Commission. The commission received 362 responses and interviewed 32 residents of the West Windsor Estates subdivision. Results of the surveys received by mail indicated that 39 percent of the respondents hire a lawn service to maintain and fertilize their lawns, 45 percent fertilize their lawns themselves, 13 percent do not fertilize at all, and 3 percent were new residents who had not made lawncare plans at the time of the survey. Of the 32 residents interviewed, about 55 percent hire a lawn service, 40 percent fertilize their lawns themselves, and 5 percent do not fertilize at all.

Lawn services in the township apply a total of about 4 lbs of nitrogen per $1,000 \mathrm{ft}^{2}$ of turf per year (lbs N/1,000 $\mathrm{ft}^{2} / \mathrm{yr}$ ) over five applications (Lawn Doctor of Mercer County, oral commun., 1993). Five respondents who apply fertilizer themselves reported an average of three applications per year at an estimated rate of about $1 \mathrm{lb} \mathrm{N} / 1,000 \mathrm{ft}^{2}$ per application. The above application rates are similar to those found by other investigators, such as Frimpter and others (1988), National Association of Home Builders National Research Center (1989), and Porter (1980). On the basis of the above data, the average fertilizer-application rate for the West Windsor Estates subdivision was estimated to be about $3 \mathrm{lbs} \mathrm{N} / 1,000 \mathrm{ft}^{2} / \mathrm{yr}$. 
Table 7. Low, medium, and high estimates of concentrations of nitrate in ground-water recharge from lawns, West Windsor Estates subdivision, West Windsor Township, New Jersey, and parameters and equations used to calculate estimates

[lbs N/ft $/ \mathrm{ft}^{2} / \mathrm{yr}$, pounds of nitrogen per square feet per year; $\mathrm{ft}^{2}$, square feet; $\mathrm{lbs} \mathrm{N} / \mathrm{yr}$, pounds of nitrogen per year; $\mathrm{mg} \mathrm{N}$, milligrams of nitrogen; $\mathrm{kg} / \mathrm{lb}$, kilograms per pound; $\mathrm{mg} / \mathrm{kg}$, milligrams per kilogram; in/yr, inches per year; $\mathrm{ft}^{3} / \mathrm{yr}$, cubic feet per year; $\mathrm{ft} /$ in, feet per inch; $\mathrm{L} / \mathrm{yr}$, liters per year; $\mathrm{L} / \mathrm{ft}^{3}$, liters per cubic foot; $\mathrm{mg} / \mathrm{L}$, milligrams per liter; $\mathrm{N}$, nitrogen]

A. Mass of nitrogen applied to lawns (lbs-N/1,000 $\mathrm{ft}^{2} / \mathrm{yr}$ )

B. Fraction of nitrogen reaching water table as nitrate

C. Average lawn size $\left(\mathrm{ft}^{2}\right)$

D. Number of lots in subdivision

E. Total mass of nitrate reaching water table (lbs N/yr), where $E=(A \times B \times C \times D) / 1,000$

F. Total mass of nitrate reaching water table $(\mathrm{mg} \mathrm{N} / \mathrm{yr})$, where $\mathrm{F}=\mathrm{E} \times(1 \mathrm{~kg} / 2.2 \mathrm{lb}) \times\left(1 \times 10^{6} \mathrm{mg} / \mathrm{kg}\right)$

G. Inches of recharge per year (in/yr)

$\mathrm{H}$. Volume of ground-water recharge $\left(\mathrm{ft}^{3} / \mathrm{yr}\right)$, where $\mathrm{H}=\mathrm{G} \times(455$ acres $) \times\left(43,560 \mathrm{ft}^{2} /\right.$ acre $) \times(1 \mathrm{ft} / 12 \mathrm{in})$

I. Volume of ground-water recharge $(\mathrm{L} / \mathrm{yr})$, where $\mathrm{I}=\mathrm{H} \times\left(28.31 \mathrm{~L} / \mathrm{ft}^{3}\right)$

J. Estimated concentration of nitrate as $\mathrm{N}$ in ground-water recharge containing nitrogen from lawn fertilizers $(\mathrm{mg} / \mathrm{L})$, where J = F / I

\section{2}

0.05

25,000

371

927

$4.21 \times 10^{8}$

20

$3.30 \times 10^{7}$

$9.34 \times 10^{8}$

.5
3

0.20

25,000

371

5,570

$2.53 \times 10^{9}$

$5.06 \times 10^{9}$

17

15

$2.81 \times 10^{7}$ $2.48 \times 10^{7}$

$7.96 \times 10^{8}$

$7.01 \times 10^{8}$

3

4

0.30

25,000

371

11,100 5 
The percentage of nitrogen applied as fertilizer that reaches the water table as nitrate depends on several factors, including soil type, soil pH, the quantity and type of fertilizer used, time of application, and the age of the lawn. Broadbent and Clark (1967) found that losses of nitrogen due to denitrification range from 1 to 75 percent, but are typically about 10 to 25 percent. The most favorable soil conditions for denitrification are high organic content, high soil-moisture content, and high soil pH (Hantzsche and Finnemore, 1992, p. 491). The soils in the West Windsor Estates subdivision have a low pH and a relatively low organic content (Soil Conservation Service, 1972, p. 45); therefore, conditions are not favorable for denitrification. The National Association of Home Builders National Research Center (1989) estimated that about one-half of the applied nitrogen reaches the water table, and more will reach the water table in areas where the lawn-fertilization rate is high. Mancino and Troll (1990), however, show that less than 5 percent of the nitrogen applied to lawns reaches the water table if the fertilizers are a slowrelease variety and are properly applied. In the West Windsor Estates subdivision, from 5 to 30 percent $\left(0.4\right.$ to $\left.1.6 \mathrm{lbs} \mathrm{N} / 1,000 \mathrm{ft}^{2} / \mathrm{yr}\right)$ of applied nitrogen is estimated to reach the water table as nitrate.

\section{Nitrate From Other Sources}

Minor sources of nitrate in ground water in the West Windsor Estates subdivision include precipitation (about $0.3 \mathrm{mg} / \mathrm{L}$ ) and domestic animal waste. Some or all of the nitrate in precipitation is removed by vegetation before the precipitation recharges the ground-water system and, therefore, was not considered in the above calculations. Porter (1980) estimates that dogs and cats produce $4.3 \mathrm{lbs}$ and $3.2 \mathrm{lbs}$ of nitrogen per year, respectively. Although data on the number of pets in the subdivision are not available, a conservative estimate of the amount of nitrogen from animal wastes that reaches the water table is less than 5 percent of the total nitrogen from septic systems and lawn fertilizers. Therefore, nitrate from animal wastes is considered to be negligible.

\section{SUMMARY AND CONCLUSIONS}

Concentrations of nitrate (as nitrogen) greater than $1 \mathrm{mg} / \mathrm{L}$ are present in ground water throughout West Windsor Township as a result of human activities. Recent (1985-93) U.S. Geological Survey ground-water-quality data for wells located in West Windsor Township indicate that concentrations of nitrate ranged from less than 0.1 to $15 \mathrm{mg} / \mathrm{L}$. The median nitrate concentration in 18 ground-water samples collected during $1985-93$ is about $8.5 \mathrm{mg} / \mathrm{L}$, the same as the median concentration for samples collected from shallow wells in agricultural areas throughout the outcrop area of the Potomac-Raritan-Magothy aquifer system. Concentrations of nitrate were greater in water from wells screened in the Potomac-Raritan-Magothy aquifer system than in water from wells open to bedrock aquifers. Past and present (1995) application of agricultural fertilizers is a major source of nitrate in ground water in the township, but on-site septic systems and fertilizers applied to lawns in residential areas also are important sources of nitrate.

The sources and input rate of nitrogen to ground water and surface water change when land is converted from agricultural to residential use. To quantify the effects of land-use change on the concentration of nitrate in ground water, samples were collected from five shallow (less than 50$\mathrm{ft}$-deep) observation wells located in the West Windsor Estates residential subdivision, which was 
constructed on formerly agricultural land. The median nitrate concentration in water from the five wells decreased from $15 \mathrm{mg} / \mathrm{L}$ in February 1989 to $10 \mathrm{mg} / \mathrm{L}$ in September 1993 . The decrease in median nitrate concentration indicates that the conversion from agricultural to residential land use could have led to a decrease in nitrogen input, but the decrease could have been caused, in part, by a lower nitrate-input rate during construction in the West Windsor Estates subdivision. The last homes in the subdivision were not completed until 1996; therefore, nitrogen loading from septic systems and lawn fertilizers had not reached the maximum when ground-water samples were collected in 1993.

Nitrate concentrations in samples collected from Bear Brook and the Millstone River in 1993 ranged from 2 to $5 \mathrm{mg} / \mathrm{L}$. Nitrate concentrations in precipitation and a stormwater runoff sample were less than $0.5 \mathrm{mg} / \mathrm{L}$. No known point sources of nitrate, such as sewage-treatment plants, are present on Bear Brook; therefore, the significant concentration of nitrate in baseflow samples indicates that nitrate is being transported to the brook by ground water. Agricultural fertilizers, lawn fertilizers, and on-site septic systems are the major sources of nitrate in the ground water that discharges to Bear Brook. If the apparent downward trend of nitrate concentrations in ground water in the vicinity continues, nitrate concentrations in Bear Brook could decrease.

Low, medium, and high estimates of nitrate in ground-water recharge from septic systems and lawn fertilizers in the West Windsor Estates subdivision were made by using average recharge rates and the estimated nitrate contribution from each source. The medium estimates for septic systems and lawn fertilizers are $4 \mathrm{mg} / \mathrm{L}$ and $3 \mathrm{mg} / \mathrm{L}$, respectively, resulting in a combined estimate of $7 \mathrm{mg} / \mathrm{L}$, which is slightly lower than the median nitrate concentration of $10 \mathrm{mg} / \mathrm{L}$ for the five ground-water samples collected in 1993. The estimated concentrations of nitrate from septic systems and lawn fertilizers in ground-water recharge could differ significantly from the actual value because most of the values used were estimated on the basis of the results of studies conducted elsewhere. If the medium estimate is accurate, however, the nitrate concentration in shallow ground water underlying the subdivision could decrease slightly over a period of years. 


\section{REFERENCES CITED}

Bauersfeld, W.R., Moshinsky, E.W., and Gurney, C.E., 1993, Water resources data, New Jersey, water year 1992-- Volume 1 - Surface-Water Data: U.S. Geological Survey Water-Data Report NJ-92-1, 507 p.

BCM Engineers, Inc., 1990, Environmental baseline study of ground and surface water conditions, West Windsor Estates II, West Windsor Township, New Jersey: Plymouth Meeting, Pa., BCM project no. 00-0598-33, 98 p.

Bergman Hatton Associates, 1992, 1992 amendment to wastewater management plan for West Windsor Township, Mercer County, N.J.: West Windsor Township, New Jersey, 19 p., 7 sheets.

Broadbent, F.E., and Clark, F., 1967, Denitrification, in Bartholomew, W.V., and Clark, F.E., eds., Soil Nitrogen: American Society of Agronomy, Inc., Madison, Wis., Agronomy Series, no. 10 , p. 344-359.

Fishman, M.J., and Friedman, L.C., 1989, Methods for determination of inorganic substances in water and fluvial sediments: U.S. Geological Survey Techniques of Water-Resources Investigations, book 5, chap. A1.

Frimpter, M.H., Donohue, J.J., and Rapacz, M.V., 1988, A mass-balance nitrate model for predicting the effects of land use on groundwater quality in municipal wellhead protection areas: Cape Cod Aquifer Management Project, Document no. 15930-56-500-5-89-C.R. (National Technical Information Service, no. PB89-134084), 41 p.

Fusillo, T.V., 1981, Impact of suburban residential development on water resources in the area of Winslow Township, Camden County, New Jersey: U.S. Geological Survey Water-Resources Investigations Report 81-27, 38 p.

Geraghty and Miller, Inc., 1972, Water resources of the upper Millstone River Basin, New Jersey: New Jersey Department of Conservation and Economic Development, Division of Water Policy and Supply, Special Report 35, 126 p.

Gronberg, J.M., Pucci, A.A. Jr., and Birkelo, B.A., 1991, Hydrogeologic framework of the Potomac-Raritan-Magothy aquifer system, northern Coastal Plain of New Jersey:

U.S. Geological Survey Water-Resources Investigations Report 90-4016, 37 p., 8 pl.

Hantzsche, N.N., and Finnemore, E.J., 1992, Predicting ground-water nitrate-nitrogen impacts: Ground Water, v. 30, no. 4.

Hary, Robert, 1990, Nitrates in groundwater, West Windsor Township: West Windsor Township, N.J., West Windsor Township Health Department Report to the Township Committee, 27 p. 


\section{REFERENCES CITED--Continued}

Hem, J.D., 1985, Study and interpretation of the chemical characteristics of natural water, 3d ed.: U.S. Geological Survey Water-Supply Paper 2254, 263 p.

Ku, H.F.H., and Simmons, D.L., 1986, Effect of urban stormwater runoff on ground water beneath recharge basins on Long Island, New York: U.S. Geological Survey WaterResources Investigations Report 85-4088, 67 p.

Lewis, J.C., and Spitz, F.J., 1987, Hydrogeology, ground-water quality, and the possible effects of a hypothetical radioactive-water spill, Plainsboro Township, New Jersey: U.S. Geological Survey Water-Resources Investigations Report 87-4092, 45 p.

Louis, J.B., and Vowinkel, E.F., 1989, Effect of agricultural chemicals on ground-water quality in the New Jersey Coastal Plain, in Weigmann, D.L., ed., Pesticides in Terrestrial and Aquatic Environments, Proceedings: Virginia Polytechnic Institute and State University, Blacksburg, Va, p. 80-89

Lyttle, P.T., and Epstein, J.B., 1987, Geologic map of the Newark 1 x 2 quadrangle, New Jersey, Pennsylvania, and New York: U.S. Geological Survey Miscellaneous Investigations Series I-1715, 2 pl.

Madison, R.J., and Brunett, J.O., 1985, Overview of the occurrence of nitrate in ground water of the United States, in National water summary--hydrologic events, selected water-quality trends, and ground-water resources, 1984: U.S. Geological Survey Water-Supply Paper 2275, p. 93-105.

Mancino, C.F., and Troll, Joseph, 1990, Nitate and ammonium leaching losses from $\mathrm{N}$ fertilizers applied to "Pencross" creeping bentgrass: HortScience, v. 25, no. 2, p. 194-196.

Murphy, E.A., 1992, Nitrate in drinking water wells in Burlington and Mercer Counties, New Jersey: Journal of Soil and Water Conservation, v. 47, no. 2, p. 183-187.

National Association of Home Builders National Research Center, 1989, A procedure to determine optimum density for homes using individual wastewater treatment systems based on nitrogen in groundwater recharge: User's guide and technical rationale: Upper Marlboro, Md., 23 p.

National Atmospheric Deposition Program, 1993, NADP/NTN annual data summary, Precipitation chemistry in the United States, 1992: Fort Collins, Colo., Natural Resource Ecology Laboratory, Colorado State University, 465 p.

New Jersey Department of Environmental Protection, 1987, Upper Millstone River Water Quality Management Study: New Jersey Department of Environmental Protection, Special Report, April 1987, 150 p. 


\section{REFERENCES CITED--Continued}

New Jersey Department of Environmental Protection, 1989, Stormwater management facilities maintenance manual: Ocean County demonstration study: New Jersey Department of Environmental Protection and Energy, 160 p.

New Jersey Department of Environmental Protection, 1990, Upper Millstone River Storm Runoff Impact Study: New Jersey Department of Environmental Protection, 180 p.

New Jersey Division of Taxation, 1973, Farmland assessment act of 1964, fourth report of data from FA-1 forms for 1972 tax year: Trenton, N.J., New Jersey Division of Taxation, 48 p.

New Jersey Division of Taxation, 1992, Farmland assessment act of 1964, twenty-third report of data from FA-1 forms for 1991 tax year: Trenton, N.J., New Jersey Division of Taxation, $56 \mathrm{p}$.

Owenby, J. R., and Ezell, D.S., 1992, Monthly station normals of temperature, precipitation, and heating and cooling degree days, 1961-90, New Jersey: National Oceanic and Atmospheric Administration, National Climatic Data Center Climatography of the United States Number $81,17 \mathrm{p}$.

Owens, J.P., and Gohn, G.S., 1985, Depositional history of the Cretaceous Series in the U.S. Atlantic Coastal Plain: Stratigraphy, paleoenvironments, and tectonic controls of sedimentation, in Poag, C.W., ed., Geology of the continental margins: New York, Van Nostrand-Wiley, p. 25-86.

Owens, J.P., and Minard, J.P., 1975, Geologic map of the surficial deposits in the Trenton area, New Jersey and Pennsylvania: U.S. Geological Survey Miscellaneous Investigations Map 884,1 sheet, scale 1:48,000.

Owens, J.P., and Minard, J.P., 1979, Upper Cenozoic sediments of the lower Delaware Valley and the northern Delmarva Peninsula, New Jersey, Pennsylvania, Delaware, and Maryland:

U.S. Geological Survey Professional Paper 1067-D, 47 p.

Perlmutter, N.M., and Koch, Ellis, 1972, Preliminary hydrogeologic appraisal of nitrate in ground water and streams, southern Nassau County, Long Island, New York: U.S. Geological Survey Professional Paper 800-B, p. 225-235.

Porter, K. S., 1980, An evaluation of sources of nitrogen as causes of ground-water contamination in Nassau County, Long Island: Ground Water, v. 18, no. 6, p. 617-625.

Pucci, A.A., Jr., Pope, D.A., and Gronberg, J.M., 1994, Hydrogeology, ground-water flow model, and saltwater intrusion of the Potomac-Raritan-Magothy aquifer system in the northern Coastal Plain of New Jersey: New Jersey Geological Survey Geological Survey Report GSR 36, 209 p., 2 pl. 


\section{REFERENCES CITED--Continued}

Soil Conservation Service, 1972, Soil Survey of Mercer County, New Jersey: Washington, D.C., $108 \mathrm{p}$.

U.S. Bureau of the Census, 1991, State and metropolitan area data book, 1991: Washington, D.C., U.S. Government Printing Office, 388 p.

U.S. Environmental Protection Agency, 1990a, Maximum contaminant levels (subpart B of part 141, National primary drinking water regulations): U.S. Code of Federal Regulations, Title 40, Parts 100 to 149, revised as of July 1, 1990, p. 559-563.

1990b, Secondary maximum contaminant levels (section 143.3 of part 143, National secondary drinking water regulations): U.S. Code of Federal Regulations, Title 40, Parts 100 to 149 , revised as of July 1,1990 , p. 674.

1980, Design manual: On-site wastewater treatment and disposal systems:

U. S. Environmental Protection Agency Report EPA-6625/1-77-008, 480 p.

Vecchioli, John, and Palmer, M.M., 1962, Ground-water resources of Mercer County, New Jersey: New Jersey Department of Conservation and Economic Development, Division of Water Policy and Supply, Special Report 19, 71 p.

Vowinkel, E.F., 1991, Comparison of relations between shallow ground-water quality and land use in two New Jersey Coastal Plain aquifer systems: U.S. Geological Survey WaterResources Investigations Report 92-4034, p. 307-313.

Vowinkel, E.F., and Battaglin, W.A., in press, Analysis of nonpoint-source ground-water contamination in relation to land use: Chapter E--Relation of ground-water quality to hydrogeology and land use in the Coastal Plain of New Jersey: U.S. Geological Survey Water-Supply Paper 2381.

1989 , Methods of evaluating the relation of ground-water quality to land use in a New Jersey Coastal Plain aquifer system: U.S. Geological Survey Water-Resources Investigations Report 88-4220, p. 405-410.

Vowinkel, E.F., and Tapper, R.J., 1995, Indicators of the sources and distribution of nitrate in water from shallow domestic wells in agricultural areas of the New Jersey Coastal Plain: U.S. Geological Survey Water-Resources Investigations Report 93-4178, 48 p.

Walker, W.G., Bouma, J., Keeney, D.R., and Magdoff, F.R., 1973a, Nitrogen transformations during subsurface disposal of septic tank effluent in sands: I. Soil transformations: Journal of Environmental Quality, v. 2, no. 4, p. 475-480.

1973b, Nitrogen transformations during subsurface disposal of septic tank effluent in sands: II. Ground water quality: Journal of Environmental Quality, v. 2, no. 4, p. 521-525. 


\section{REFERENCES CITED--Continued}

West Windsor Township Environmental Commission, 1990, Stream Water Quality: West Windsor Township, N.J., 65 p.

West Windsor Township Environmental Commission, 1994, Stream Water Quality, Appendix B-Report update: West Windsor Township, N.J., 12 p.

Widmer, Kemble, 1965, Geology of the ground water resources of Mercer County: New Jersey Department of Conservation and Economic Development, New Jersey Geological Survey, Geologic Report Series No. 7, 115 p.

Wood, W.W., 1976, Guidelines for collection and field analysis of ground-water samples for selected unstable constituents: U.S. Geological Survey Techniques of Water-Resources Investigations, book 1, chap. D2.

Zapecza, O.S., 1989, Hydrogeologic framework of the New Jersey Coastal Plain: U.S. Geological Survey Professional Paper 1404-B, 49 p., 24 pl. 


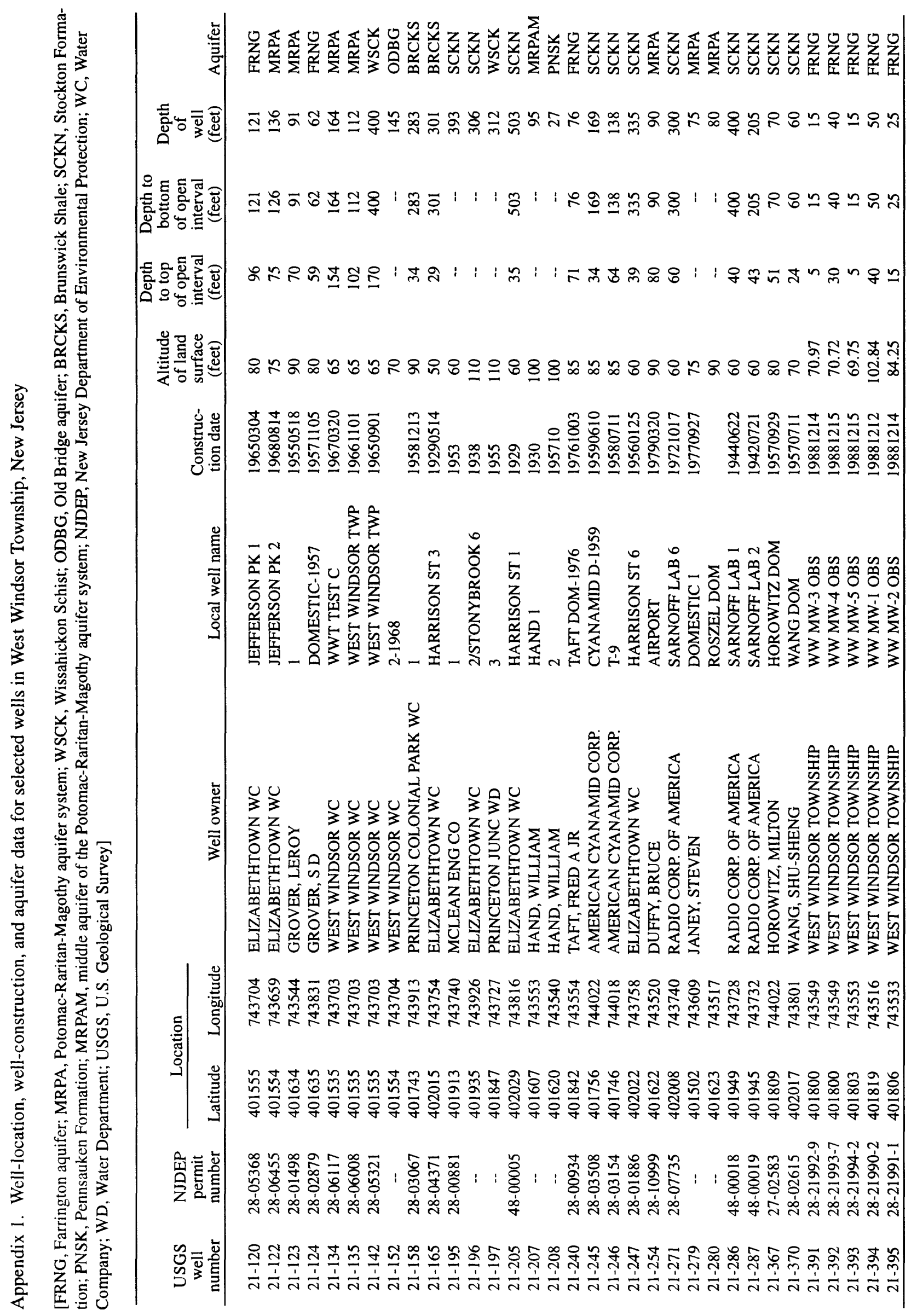

